\title{
The pricing discount for limited liquidity: Evidence from SWX Swiss Exchange and the Nasdaq
}

September 6, 2003

Claudio Loderer*

Institut für Finanzmanagement, Universität Bern email: claudio.loderer@ifm.unibe.ch

\section{Lukas Roth}

Institut für Finanzmanagement, Universität Bern email: lukas.roth@ifm.unibe.ch

\begin{abstract}
We investigate the pricing discount for limited liquidity. Unlike previous studies that have examined the relation between historical returns and liquidity, ours looks directly at current stock prices. This approach requires less data and yields up-todate information about limited liquidity discounts. We analyze data from the Swiss exchange and the Nasdaq during 1995-2001, and find a statistically and economically significant price-liquidity relation in both markets. We test the robustness of that relation with a procedure that does not rely on specific distributional assumptions. Our findings are unaffected. Accordingly, the discount suffered by the least liquid securities is about $30 \%$.
\end{abstract}

Keywords: Liquidity; Asset pricing; Bid-ask spread

JEL classification: $G 12, G 31$

\footnotetext{
${ }^{*}$ Corresponding author: Engehaldenstrasse 4, 3012 Bern, Switzerland. Comments are welcome.

We are grateful to the SWX Swiss Exchange and its former CEO, Antoinette Hunziker, for providing the intradaily bid-ask spread data used in this study. We also wish to thank an anonymous referee for the valuable criticism and Nancy Macmillan for the great editorial help. We have benefited from the help and comments of Petra Joerg, Giovanni Leonardo, Urs Peyer, Karl Pichler, Tina Purtschert, Kurt Schmidheiny, Urs Wälchli, and Pius Zgraggen.
} 


\title{
The pricing discount for limited liquidity: \\ Evidence from SWX Swiss Exchange and the Nasdaq
}

\begin{abstract}
We investigate the pricing discount for limited liquidity. Unlike previous studies that have examined the relation between historical returns and liquidity, ours looks directly at current stock prices. This approach requires less data and yields up-to-date information about limited liquidity discounts. We analyze data from the Swiss exchange and the Nasdaq during 1995-2001, and find a statistically and economically significant price-liquidity relation in both markets. We test the robustness of that relation with a procedure that does not rely on specific distributional assumptions. Our findings are unaffected. Accordingly, the discount suffered by the least liquid securities is about $30 \%$.
\end{abstract}




\section{The pricing discount for limited liquidity: Evidence from SWX Swiss Exchange and the Nasdaq}

\section{Introduction}

The purpose of this paper is to find out how to value firms that trade in less than perfectly liquid markets and the investment projects these firms undertake. To do so, we empirically examine the discount for limited liquidity that market participants impose when pricing stocks.

When discussing the valuation of investment projects, most finance textbooks recommend estimating the projects' future mean net cash flows and discounting them with an appropriate risk-adjusted discount rate. No reservations are generally made. A given project should have the same value regardless of what firm undertakes it.

As it turns out, this logic implicitly assumes unlimited investor clienteles, since uninhibited trading among investors is needed to guarantee that a given project commands the price that theory implies. If the project is valued more highly, investors will avoid investing in it and will try to short it. If it is valued less highly, investors will flock to it hoping to earn an abnormal return. Whatever the mispricing, investors' reaction will tend to force the price to converge to its intrinsic value (see also Shleifer and Vishny, 1997). ${ }^{1}$

The problem is that financial assets trade in markets with limited liquidity. Thus market trading might not correct mispricing. Yet if investors are not sure that the prices they can deal at are right, they will be reluctant to trade. In particular, they will hesitate to buy, unless offered an illiquidity discount, particularly for firms where the probability of mispricing is higher. Illiquid firms are those that are more expensive to trade. The more substantial the impediments to trading, the higher the required discount. Practitioners have long recognized this phenomenon. In Switzerland, they recommend adding a limited-tradability premium between $1 \%$ and $3 \%$ to the discount rate used in firm valuation.

The empirical literature reports evidence consistent with an illiquidity discount. Several studies investigate the relation between historical returns and various liquidity

\footnotetext{
Black (1986) makes essentially the same argument when discussing the difference between price and value of a stock.
} 
proxies, and generally find a negative return-liquidity relation. ${ }^{2}$ We are also interested in that relation. However, we investigate the pricing relevance of limited liquidity by looking directly at stock prices. The benefit of this approach is that it uncovers the current relation between value and liquidity (as opposed to the historical relation, as with the return-based approach). This could be an important benefit since that relation appears to change over time. Our approach also avoids the problem of insufficient time-series data to measure mean returns.

Our investigation starts with an analysis of the firms traded on the SWX Swiss Exchange in the year 2000. We then replicate the analysis with two control samples. The first includes once again the firms traded on the SWX Swiss Exchange in 19951999 and in the year 2001. The second includes the firms traded on the Nasdaq in 1995-2001. This second sample enables international comparisons between a well researched capital market (the U.S. market) and a fairly unknown one (the Swiss market). We find significant evidence consistent with the existence of a discount for limited liquidity. The discount can be sizable; for the least liquid stocks in our sample, it equals about $30 \%$.

The remainder paper is organized as follows. The next section discusses limited liquidity and its impact on firm value in more detail. Section 3 summarizes the test design. Section 4 presents the data, their sources, and their characteristics. Section 5 examines the results of the investigation, and section 6 draws conclusions and formulates practical implications.

\section{Theoretical considerations}

\subsection{Limited liquidity and project value}

To calculate the value of an investment project $^{3}$ textbooks generally recommend projecting the mean net cash flows the project will generate and discounting them with an appropriate risk-adjusted discount rate. ${ }^{4}$ As an illustration,

\footnotetext{
There is also inconsistent evidence. See, in particular, Chen and Kan (1995).

3 The term investment project is used very generally and includes the buying and selling of firms themselves.

4 To keep things simple, we ignore Fama's (1996) reservations about the textbooks' rendition of the theory of valuation.
} 
assume, for simplicity, that investments are undertaken by corporations and are all equity-financed. Accordingly, the following project:

\begin{tabular}{ll}
\hline Initial investment & USD 10 million \\
Expected perpetual net cash flow & USD 8 million \\
Risk-adjusted discount rate & $20 \%$ \\
\hline
\end{tabular}

has a value of:

$$
\mathrm{NPV}=-10+\frac{8}{0.2}=\mathrm{USD} 30 \text { million }
$$

Yet assuming this is indeed how market participants compute the value of investment opportunities, what guarantees that the project is really worth USD 30 million? The answer is trading by market participants.

If the firm's aggregate equity value increases by less than USD 30 million when this investment is announced, the company's stock will be undervalued. Investors could then buy a majority position in the firm and either sell the project as a separate entity in the hope of obtaining a higher price, or hold their stake and pocket their share of the USD 8 million cash the project is expected to generate every year. The incentive to buy goes away when the project raises the market value of the firm's equity by at least USD 30 million. Conversely, if the firm's share price increases by more than USD 30 million, shareholders will be inclined to sell, and other investors will either be discouraged from buying or be tempted to short shares in the expectation of a price decline. This will cause the share price to fall. The incentive to sell or short will go away when the share price correctly reflects the project's value.

For the trading mechanism to be effective, however, the project must be tradable either directly (as a separate firm) or indirectly (as part of a traded firm). In reality, tradability is generally limited. Limited tradability can occur because: (a) the firm that undertakes the project is not traded and managers do not want to spin off, divest, or otherwise sell the project; (b) the firm's investor clientele is finite and unwilling, as a result of risk aversion, to engage in large transactions (Merton, 1982, and Black, 1986); (c) the clientele, being unaware of the project's mispricing or facing limited wealth, does not trade or is unable to to so (see Shleifer and Vishny, 1997); (d) investors follow a buy-and-hold policy with a long horizon. The greater the reluctance to trade or the tighter the limits to trading, the larger the likelihood that 
the company's share price will not correspond to its true, intrinsic value. But if investors cannot be sure that the share price of a given firm reflects its true value, they will also pay less for its shares, which will therefore sell at a discount from true value. The same can be said about the project in our preceding example. The project will probably be worth close to USD 30 million to a highly liquid firm. To a firm that does not trade very often, however, it will not be worth that much, simply because no effective trading mechanism guarantees a value of USD 30 million.

Limited tradability is synonymous with limited liquidity. Assets that are expensive to trade are also expensive to liquidate or to turn into cash. In keeping with the literature, we will therefore speak about limited liquidity (or illiquidity). The implication of this phenomenon is that there should be a negative relation between asset value and illiquidity. An example of what can happen to prices when assets are illiquid is the case of Nestlé's registered and bearer shares in the 1980s. Any investor could hold bearer shares. In contrast, until 1988, only domestic investors acceptable to the board could hold registered shares. The investor clienteles of these shares was therefore limited (Merton, 1982) - i.e., their tradability was restricted. Not surprisingly, the price of Nestlé registered shares (properly adjusted to reflect the same claim to future cash flows) traded at a 50\% discount from the bearer shares (see Loderer and Jacobs, 1995, and Stulz and Wasserfallen, 1995).

\subsection{Limited liquidity and the bid-ask spread}

Ultimately, all the impediments to trading increase the effective costs of that activity. It is debatable, however, whether transaction costs significantly affect longrun returns (for a survey of the literature see Easley and O'Hara, 2001). In Constantinides (1986), investors trade infrequently, meaning that transaction costs are small compared to holding-period returns. In Amihud and Mendelson (1986), the opposite is true. The significance of transaction costs therefore seems to depend on investors' horizons. Consistent with this argument, Chalmers and Kadlec (1998) report evidence that it is the amortized rather than the regular spread that appears to 
get priced - the amortized spread measures the annualized cost of the spread to investors as a group. ${ }^{5}$

The logic of the Chalmers and Kadlec analysis, however, is not fully convincing. ${ }^{6}$ Adding up transaction costs across trades seems to exaggerate the significance of transaction costs. To see why, ignore interest rates and assume that investors trade a pot that contains $\$ 1,000$, which can be distributed at year-end. Suppose each trade of the pot costs $\$ 1$. If so, the last investor will be willing to pay $\$ 999$ for it. And the next-to-last will pay $\$ 998$ so as to be able to cover his transaction costs. Rolling back the argument, would seem to imply that the current pot price equals $\$ 1,000-n$, where $n$ is the anticipated number of trades. Of course, the price implied by this logic is too low. Given a price lower than $\$ 999$, any investor can step in, pay the market price, wait until the end of the year, and make an arbitrage profit. The market price will be $\$ 999$ and thereby reflect the costs of just one transaction. The same happens in the real world. Investors can step in and either hold a given asset over the long run or liquidate it. Thus, the relevance of transactions costs cannot be measured by adding up these costs across trades over an arbitrary horizon.

It would be reductive, however, to think of transaction costs simply as a tax on gross returns. Transaction costs also have an indirect effect, which arises from the fact that, if they discourage trading, there will be limits to price equilibration. As we just argued, in the absence of the equilibrating mechanism of trading, prices can be arbitrary and investors will not always be able to trust them. This will induce a pricing discount too.

In our investigation, we use the bid-ask spread as an indicator of the cost of trading a given security - the cost of "immediate execution" according to Amihud and Mendelson (1986). ${ }^{7}$ The bid-ask spread is therefore our main proxy for limited

5 The amortized spread equals the product of the effective spread and the number of shares traded summed over all trades for each day, and expressed as an annualized fraction of equity value.

6 It is also counterintuitive: assets that are almost never traded can in principle end up being more "liquid" than assets that are heavily traded.

7 Several factors determine the bid-ask spread in a security: order handling costs, non competitive pricing, inventory risk, the options implicitly granted to the rest of the market, and asymmetric information (see Stoll, 2002; see also Huang and Stoll, 1997, and Glosten and Harris, 1988). Which component matters most in affecting prices is immaterial here. All we want to know is whether the cost of immediacy (the cost of liquidity) affects security prices. 
tradability or liquidity (see also the discussion in Amihud, 2002). ${ }^{8}$ In doing so, we concede that it is debatable whether bid-ask spreads measure liquidity correctly (see Grossman and Miller, 1988, and Easley and O'Hara, 2001). ${ }^{9}$ Other (or additional) measures have been suggested, including: effective spread; realized spread; amortized spread (Chalmers and Kadlec, 1998); share turnover (i.e., number of shares traded divided by number of shares outstanding; or value of trading divided by value of shares outstanding; Datar, Nair, and Radcliffe, 1998); dollar volume (Brennan, Chordia, and Subrahmaniam, 1998); market depth; and price impact of trading (defined by Breen, Hodrick, and Korajczyk, 2002, as the relation of price changes and net turnover; and by Amihud, Mendelsohn, and Lauterbach, 1997, as the ratio of daily volume divided by the absolute value of the daily return). ${ }^{10}$ We will therefore inquire into trading volume as an alternative measure of liquidity.

\section{Test design}

We investigate the relation between liquidity and stock prices with a crosssectional regression approach. To set a general framework, let us look at stock prices as the present value of a constantly growing dividend flow and write:

$$
\text { Stock price (ex-dividend): } \mathrm{P}=\frac{\mathrm{DIV}_{0} \times(1+\mathrm{g})}{\mathrm{k}-\mathrm{g}} \text {, }
$$

where $\mathrm{DIV}_{0}$ is the current dividend per share, $\mathrm{g}$ the expected rate of growth of dividends, and $\mathrm{k}$ the required rate of return on the stock. Under the assumption of a constant payout ratio $(\pi)$, this model is often rewritten by replacing the current dividend payment by the product of the firm's current earnings per share (EPS) and

8 Several factors affect the bid-ask spread in a security, namely the dealers' order handling costs, non-competitive pricing, the inventory risk of the suppliers of immediacy, the value of the option granted to investors, and the costs of having to trade with investors with better information (Stoll, 2002).

9 See also Amihud and Mendelson (1986, 2000), Amihud, Mendelson, and Uno (1999), Bajaj, Denis, Ferris, and Sarin (2001), Brennan and Subrahmanyam (1996), Easley, Hvidkjaer, and O'Hara (2002), Eleswarapu (1997), Koeplin, Sarin, and Shapiro (2000), and Silber (1991). Studies that have found indirect evidence of the pricing relevance of liquidity include Shleifer (1986), Harris and Gurel (1986), Bagwell (1992), Loderer and Jacobs (1995), Stulz and Wasserfallen (1995), and Galloway, Loderer, and Sheehan (1998).

10 See also Jones and Lipson (1999) and Engle and Patton (2004). 
the payout ratio. Doing so and rearranging terms we obtain an expression for $\mathrm{P} / \mathrm{E}$ ratios, namely:

$$
\mathrm{P} / \mathrm{E} \text { ratio: } \frac{\mathrm{P}}{\mathrm{EPS}_{0}}=\frac{\pi \times(1+\mathrm{g})}{\mathrm{k}-\mathrm{g}} \text {. }
$$

According to this expression, $\mathrm{P} / \mathrm{E}$ ratios are, among other things, a positive function of the payout ratio and the expected rate of earnings growth, and a negative function of the required rate of return on the stock.

From equation (2), a cross-sectional regression of $\mathrm{P} / \mathrm{E}$ ratios against their possible determinants should include payout ratios, expected rates of earnings growth, and required rates of return. We perform such a regression. Since in a cross-sectional comparison risk-free rates and market risk premiums are the same across observations, if we want to control for different required rates of return, $\mathrm{k}$, we have to control for differential risk. We therefore include a risk variable in the regression arguments. Moreover, since the evidence suggests that average stock returns (and therefore stock prices) are affected by firm size, we add this variable as well. More importantly, in our effort to assess the pricing relevance of liquidity, we examine whether the inclusion of liquidity adds to the explanatory power of the regression. We therefore model $\mathrm{P} / \mathrm{E}$ ratios with the following function:

$$
\text { P/E ratio } i=f\left(\text { Growth }_{\mathrm{i}}, \text { Payout }_{\mathrm{i}}, \text { Risk }_{\mathrm{i}}, \text { Size }_{\mathrm{i}}, \text { Liquidity }_{\mathrm{i}}\right) \text {, }
$$

where the index i identifies a particular firm and the arguments are defined as follows:

$$
\begin{array}{ll}
\text { Growth } & =\text { expected rate of earnings growth; } \\
\text { Payout } & =\text { firm's payout ratio; } \\
\text { Risk } & =\text { risk of the stock in question; } \\
\text { Size } & =\text { market value of the firm's equity; } \\
\text { Liquidity } & =\text { stock's liquidity. }
\end{array}
$$

Equation (3) is consistent with the regression specifications tested in the return-liquidity literature. From that literature, the coefficients associated with growth, size, and liquidity should be positive; based on equation (2), payout should also have 
a positive coefficient, although there is little if any evidence to support this prediction; and risk should have a negative coefficient. Note that these are all relations that involve price, not EPS. The exception is the relation between risk and P/E ratios. All else being the same, risk correlates negatively with price and positively with EPS. The other relations do not share a similar ambiguity. In particular, the extant empirical findings of a positive relation between historical returns and liquidity imply that a negative relation between $\mathrm{P} / \mathrm{E}$ ratios and liquidity would have to be a relation between liquidity and price, not liquidity and EPS. We will rely on this argument when interpreting the empirical results.

\section{Original-sample characteristics}

The original sample covers the firms traded on the SWX Swiss Exchange. Since firms typically have more than one class of stock outstanding, we focus on the class with the lowest bid-ask spread. Given that we are interested in establishing a relation between liquidity and stock prices, this selection criterion should not carry any substantial prejudice.

There are 250 firms listed on the SWX in June 2000. The I/B/E/S database from which we gather EPS-forecast information, however, provides data only for a subset of them; we exclude 103 firms with no such forecasts. Financial analysts do not follow these companies closely, possibly because they have a market capitalization of less than CHF 23 million (USD 16 million assuming an exchange rate of CHF 1.4 to the dollar). We also exclude 15 firms with negative EPS to avoid negative $\mathrm{P} / \mathrm{E}$ ratios. These latter firms represent a problem because, as argued in the following section, the regression specification we eventually choose is one where we take the natural logarithm of $\mathrm{P} / \mathrm{E}$ ratios. Another 8 firms lack other data required in the analysis. That leaves us with a sample of 124 firms.

The cross-sectional analysis in equation (3) is performed as of June 30, 2000. The variables in the equation are measured as follows:

P/E ratio: stock price observed on June 30, 2000 divided by EPS reported for 1999. We refer to the natural logarithm of this variable as $\ln (\mathrm{P} / \mathrm{E})$. Price data are provided by SWX; EPS data are from the $\mathrm{I} / \mathrm{B} / \mathrm{E} / \mathrm{S}$ database; 
Expected earnings growth: measured in two ways. The first is the growth-rate prediction (relative to 1999) implicit in financial analysts' average EPS forecasts for the year 2000 as reported on June 30,2000 in the $\mathrm{I} / \mathrm{B} / \mathrm{E} / \mathrm{S}$ database. We label this variable EPSg2000. The second proxy is the growth-rate prediction implicit in financial analysts' average EPS forecasts for 2001 (relative to 2000) as reported on June 30, 2000 in the same database. We label this variable EPSg2001;

Payout ratio: dividends paid in 1999 on the stock in question divided by EPS reported for the same year. Dividend data are from the yearly stock guide Schweizerischer Aktienführer. We label this variable PAYOUT;

Risk: slope coefficient of a market model estimated with monthly returns over the period 1.1.1997 to 6.30.2000. In that model, the market portfolio is approximated with the Swiss Performance Index (SPI), an index that contains all firms traded on the SWX. The computation assumes internationally segmented markets (Stulz, 1995a; Stulz, 1995b). We refer to this variable as BETA. Alternatively, we measure risk with the standard deviation of return over the same period of 1.1.1997 to 6.30.2000 and label that variable STDEV;

Firm size: natural logarithm of the product of number of shares outstanding times average monthly stock price observed during the first six months of 2000 . We refer to this variable as LNSIZE. ${ }^{11}$ As mentioned above, if the firm in question has more than one class of stock outstanding, we take the most liquid one (in terms of bid-ask spread). Information on the number of shares outstanding is from Schweizerischer Aktienführer;

Liquidity: average relative bid-ask spread, defined as the ratio of the difference between ask and bid price, divided by the bid price. ${ }^{12}$ Intradaily bid-ask spread data are from the SWX. Trading on the SWX is electronic. Its bid-ask spreads are therefore not necessarily quotes posted by market makers but could reflect limit orders of individual investors. The average we use is computed over the period 1.1.1997 to 6.30 .2000 using two daily observations (one at 10 a.m., the other at 4 p.m.). From the SWX database, we drop all observations for which the bid is smaller than or equal to the ask quote (this error in the database occurs in 10,294 out of 176,869 cases, with a frequency of $5.8 \%)$. We refer to this variable as RELSP.

Descriptive statistics for the variables in the regression are reported in Table 1 below. As can be seen from the standard deviations, there is fairly wide variation in both $\mathrm{P} / \mathrm{E}$ ratios and bid-ask spreads. Hence, there is something to explain, and liquidity could contribute to that explanation. All the other explanatory variables in the table also display wide variation. Moreover, all variables have sample distributions that are skewed right. The bid-ask spread, for instance, has an average of $1.68 \%$ and a median of $1.37 \%$. The median equity value is CHF 1,027 million (USD 734 million with an exchange rate of CHF 1.40 to the dollar), the median P/E

11 The results are virtually unchanged when we measure LNSIZE by the market capitalization on June 30, 2000 instead.

12 Evidence of a liquidity effect in Swiss stock prices is reported in Gardiol, Gibson-Asner, and Tuchschmid (1997). Liquidity is measured there as the proportion of freely negotiable shares in the capital structure. 
ratio is about 18.93 , and median expected earnings growth equals $14.4 \%$ for the year 2000 and $16.2 \%$ for 2001 .

\section{Empirical results}

This section presents and discusses the empirical results. For ease of exposition, it falls into three parts. In the first, we examine the original sample. We start with the analysis of a simplified version of equation (3) and its statistical properties. Then we use that information to test the price-liquidity relation postulated in equation (3) with an ordinary least squares (OLS) regression approach. Finally, we reexamine the relation with a procedure that is robust with respect to distributional and other standard assumptions concerning the regression residuals. Part two investigates whether the results can be duplicated with two holdout samples. The final part interprets the results.

\subsection{Original sample}

\subsubsection{Preliminary analysis}

We first test the following specification of equation (3):

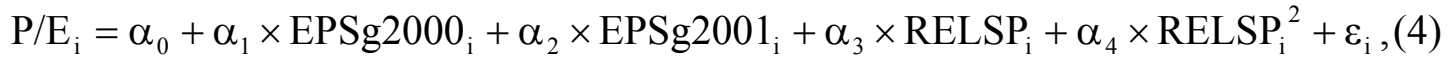

where the variables are defined as above, the subscript $i$ refers to firm $i$, the $\alpha_{i}$ 's are regression coefficients, and $\varepsilon_{\mathrm{i}}$ is an error term with the usual ordinary least squares (OLS) properties. This initial specification postulates a nonlinear price-liquidity relation, consistent with the results reported in the literature (see especially Amihud and Mendelson, 1986, and Brennan and Subrahmanyam, 1996).

The estimation results are shown in Table 2. All variables in the regression have highly significant coefficients with confidence 0.95 or better. The F-test value for the regression as a whole is also highly significant, and the adjusted $\mathrm{R}^{2}$ indicates that the estimated relation explains a sizable fraction (86.5\%) of the cross-sectional variation in $\mathrm{P} / \mathrm{E}$ ratios. Both measures of expected earnings growth have the postulated positive coefficient. Specifically, the expected growth rate one year ahead $($ EPSg2000) has a coefficient of $36.426(t-v a l u e=27.306)$, compared with the 
coefficient of $89.025(\mathrm{t}$-value $=2.930)$ found for the growth rate expected two years hence (EPSg2001). The obvious interpretation is that higher expected earnings growth signals higher future residual cash flows. Moreover, the bid-ask spread (RELSP) has a negative and its squared term $\left(\right.$ RELSP $\left.^{2}\right)$ a positive coefficient. The net effect is negative, at least over a range of bid-ask spread values up to $11 \%$. This is partly consistent with the hypothesized sign. A marginal 1 percent increase in the bid-ask spread, for instance, would depress the $\mathrm{P} / \mathrm{E}$ ratio by about $12[=-1,320.40 \times$ $\left.0.01+12,039.68 \times 0.01^{2}=-12\right]$. The table further reports a fairly large positive and significant intercept estimate, an indication that we may have left out some relevant variables. As indicated in equation (3), firm size, risk, and payout ratio could be among them.

In spite of its explanatory power, one problem with specification (4) is that it yields nonnormal residuals. The studentized range of these residuals is in fact 10.85, a value that rejects normality with confidence better than 0.99 and questions the significance tests reported in Table 2. As it turns out, taking the natural logarithm of the $\mathrm{P} / \mathrm{E}$ ratios yields residuals that follow a more normal distribution. The studentized range of the residuals from that specification (not shown) is 5.56, which fails to reject normality at the usual confidence levels.

Related to this, there could be an outlier problem. Two observations appear to seriously affect our estimates. ${ }^{13}$ The first refers to Unaxis, a firm that resulted from the restructuring of Oerlikon Bührle. Because of that restructuring and the associated writeoffs, Unaxis's 1999 earnings are close to zero. The P/E ratio is consequently very high $(1,108)$. The second observation concerns the firm EL Simplon. Its bid-ask spread is more than $12 \%$, double the next highest value in the sample. When we reestimate the regression equation (4) without these observations, the coefficient of RELSP $^{2}$ becomes insignificantly different from zero.

Yet another problem with regression (4) is heteroskedasticity. A CookWeisberg test has a chi-squared value of 550.87, which rejects homoskedasticity with confidence better than 0.99 . This biases the estimated standard error of the regression and represents one more reason to question the significance tests reported in the table.

13 These two observations have a so-called high leverage. For a discussion of leverage in the context of outlier analysis, see Judge, Hill, Griffiths, Lütkepohl, and Lee (1988), p. 892. 


\subsubsection{OLS-regression results}

The preceding results imply a regression specification in which the dependent variable is the natural logarithm of the $\mathrm{P} / \mathrm{E}$ ratio, the regression arguments include firm size (LNSIZE), payout ratio (PAYOUT), and risk (BETA), and the regression is estimated with a White correction procedure. The regression specification we are interested in is therefore the following:

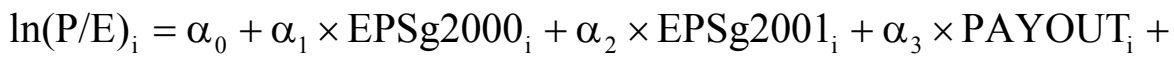

$$
\begin{aligned}
& +\alpha_{4} \times \mathrm{BETA}_{\mathrm{i}}+\alpha_{5} \times \mathrm{LNSIZE}_{\mathrm{i}}+\alpha_{6} \times \mathrm{RELSP}_{\mathrm{i}}+\varepsilon_{\mathrm{i}}
\end{aligned}
$$

where the different variables are as defined above. Because this specification is nonlinear, we drop the squared value of the relative spread $\left(\mathrm{RELSP}^{2}\right)$ from the regression arguments. The estimation results are shown in column (1) of Table 3. We show those obtained when dropping the two observations Unaxis and EL Simplon. We will come back to the issue of outliers and, more generally, nonnormal residuals in section 5.1.3.

The regression intercept is still significantly different from zero. If we inspect the column of results further, we see that expected earnings growth once more has the predicted positive and significant coefficient, regardless whether we look one or two years ahead (EPSg2000 and EPSg2001, respectively). Of the new variables, PAYOUT has an insignificant coefficient, whereas BETA has a negative and significant one. This is consistent with the notion that BETA is a relevant risk measure. We also find that the log of the market value of equity (LNSIZE) has a positive and significant coefficient. The positive sign could indicate that larger firms are less risky and therefore command higher stock prices (see also the literature on size effects, including Banz, 1981; Fama and French, 1993). The coefficient of the bid-ask spread (RELSP), however, is insignificantly different from zero at the usual confidence levels. One possible reason is that there is no price-liquidity relation. Another is that LNSIZE is a measure of both risk and liquidity.

Consistent with the latter interpretation, the correlation coefficient between equity value and bid-ask spread is -0.799 . Large firms tend to have tighter bid-ask spreads, which means that firm size could also be a proxy for liquidity.

For practical valuation purposes, the analysis could stop here, since the results in column (1) of Table 3 tell us that large firms are more highly valued than small 
firms. Whether the reason is risk or limited liquidity would be immaterial. We could therefore impute the discount imposed on smaller firms by the market, and use that discount to value the investment projects undertaken by smaller firms. As it turns out, we obtain similar results when we replicate the regression with a different measure of size, namely the book value of the firm's assets. The benefit of that specification is that it yields a size coefficient that can be applied also in the case of nontraded firms.

Our purpose, however, is to assess the impact of limited liquidity on value. We therefore have to disentangle the possible risk and liquidity effects in the coefficient of LNSIZE in our regression. We unravel the two effects in question by regressing firm size on bid-ask spread. That regression tells us what part of the crosssectional variation in firm size is due to the cross-sectional variation in liquidity and what part is not. Specifically, we estimate the following regression equation:

$$
\operatorname{LNSIZE}_{\mathrm{i}}=\mu_{0}+\mu_{1} \times \operatorname{RELSP}_{\mathrm{i}}+\eta_{\mathrm{i}}
$$

where $i$ is once again an index that identifies a particular firm in our sample of 122 , and $\eta_{\mathrm{i}}$ is an error term with the usual OLS properties. Estimated over the 1.1.19976.30.2000 period, this pooled time-series, cross-sectional regression has an adjusted $\mathrm{R}^{2}$ of $63.5 \%$ and a bid-ask spread coefficient of -119.23 with a t-statistic of -14.552 (not shown). By construction, the residuals from this regression are unrelated to liquidity (as measured by the bid-ask spread) and therefore capture size effects net of liquidity effects. We call these residuals RES-SIZE/RELSP and use them in our regression in lieu of the variable LNSIZE. We hasten to add that one could also regress the bid-ask spread against firm size and use the residual from that regression to capture possible liquidity effects unrelated to size. Our interest, however, is not so much in distinguishing size-related from size-unrelated liquidity effects, but rather the liquidity-related from the liquidity-unrelated size effects. The new regression specification is therefore the following:

$$
\begin{aligned}
& \ln (\mathrm{P} / \mathrm{E})_{\mathrm{i}}=\alpha_{0}+\alpha_{1} \times \mathrm{EPSg} 2000_{\mathrm{i}}+\alpha_{2} \times \mathrm{EPSg} 2001_{\mathrm{i}}+\alpha_{3} \times \mathrm{BETA}_{\mathrm{i}} \\
& +\alpha_{4} \times \text { RES-RELSP }_{\mathrm{i}}+\alpha_{5} \times \text { RELSP }_{\mathrm{i}}+\varepsilon_{\mathrm{i}}
\end{aligned}
$$

Note that we dropped the variable PAYOUT as it does not have a significant coefficient. Estimation results for this specification are displayed in column (2) of 
Table 3. As shown there, the adjusted $\mathrm{R}^{2}$ is slightly higher than that in column (1) of Table 3, and the F-statistic remains highly significant. All the variables have coefficients that are significantly different from zero with confidence of at least 0.99 , and all have the predicted sign. Specifically, the coefficients for earnings growth are positive whether we look one or two years ahead; the coefficient of risk (BETA) is negative; and the coefficient of RES-SIZE/RELSP is positive, with a value of 0.126 and a t-statistic of 3.804. This latter result confirms our original assertion that (net) size could capture aspects of risk not measured properly by the firm's equity beta; accordingly, larger firms are less risky and therefore command, all else being the same, higher prices. More importantly, the bid-ask spread in column (2) of Table 3 has a negative and significant coefficient (-18.077 with a t-statistic of -5.016). As predicted, a larger spread reduces equity value.

\subsubsection{Issues of statistical robustness}

Before proceeding with the analysis, we discuss the normality of the residuals. Figure 1 below plots the kernel density estimates of the regression residuals and compares them with the theoretical normal density. The relevant regression coefficients are those in column (2) of Table 3. Visual inspection suggests the presence of skewness. A skewness test is significant with confidence better than 0.95 .

The problem with nonnormal residuals is that they are inconsistent with our tand F-tests. It is not clear from inspection, however, which way the bias goes. Various approaches have been suggested to obtain regression coefficient estimators that are robust with respect to the distribution of the error terms. ${ }^{14}$ We employ a combination of the algorithms developed by Huber and Tukey as implemented in the Intercooled Stata 6.0 statistical package. This method starts with the OLS regression estimates, calculates the residuals, and weighs the observations in accordance with the size of their residuals. Observations with large residuals are given low weights. The regression equation is then reestimated as a weighted least squares regression. Residuals from this regression are computed and used to revise the weights assigned to the observations. The weighted least squares regression is reestimated using the revised weights. This procedure is repeated until the regression parameters converge.

14 For a discussion of the issues involved, see Chapter 22 of Judge, Hill, Griffiths, Lütkepohl, and Lee (1988) or Chapter 6 in Hamilton (1992). 
We apply this procedure to compute the regression coefficients. The variable RES-SIZE/RELSP, which we use to capture net size effects, is also estimated with a robust regression procedure. The results are shown in Table 4. A few things are worth noting when comparing these results to those obtained previously in column (2) of Table 3. First, none of the coefficients have changed in sign. Second, the probability values of the t-tests of significance for the individual parameters are essentially the same.

\subsection{Holdout samples}

\subsubsection{Holdout-sample characteristics}

To test our results, we use two holdout samples. The first covers the SWX during a 5-year period preceding the original sample year and during the year thereafter, i.e., 1995-1999 and 2001. The second refers to the Nasdaq during 19952001. Table 5 reports the selection criteria and the resulting annual sizes of these samples. To be included in our samples, companies have to be in the $\mathrm{I} / \mathrm{B} / \mathrm{E} / \mathrm{S}$ database of earnings forecasts, they have to report positive earnings during the year in question, they have to have sufficient monthly return data to compute their beta coefficients, and they have to have sufficient bid-ask spread data. Betas are computed with monthly returns over the past 4.5 years; we require 50 of the possible 54 monthly observations to include a particular firm in the sample. Bid-ask spreads are computed as daily averages over the past 2.5 years; we require 600 of the possible 625 daily observations to add a particular firm to the sample. Missing values can occur by chance or because a firm is not quoted during the period in question. The results do not change significantly when we apply less restrictive sample selection criteria. As one can see from the table, the resulting sample sizes oscillate between 113 and 128 for SWX companies, and between 450 and 664 for Nasdaq companies.

The data used in the analysis of these holdout samples are defined similarly as in the original sample except for the following items. For the SWX sample, the bidask spread is taken from Datastream and corresponds to the closing quote. Moreover, earnings forecasts for 1995-1999 are from Datastream. For the Nasdaq sample, EPS data are from $\mathrm{I} / \mathrm{B} / \mathrm{E} / \mathrm{S}$, everything else is taken from the Center for Research in Securities Prices (CRSP) tapes. The market portfolio used to measure risk is the Swiss Performance Index (SPI) and the Nasdaq Composite Index for SWX and 
Nasdaq firms, respectively. The results are the same when we use the CRSP ValueWeighted Index for Nasdaq firms.

Table 6 presents descriptive statistics for the two holdout samples. A comparison indicates that Nasdaq firms have slightly higher $\mathrm{P} / \mathrm{E}$ ratios throughout the sample period. According to the expected earnings-growth figures, this seems to occur because financial analysts project higher earnings growth for Nasdaq than for SWX firms, particularly two years ahead $\left(\mathrm{EPS}_{\mathrm{g}, \mathrm{t}+2}\right)$. The table also shows that companies in either sample have beta estimates smaller than one. That does not mean that these firms represent little risk in an absolute sense. Remember that these coefficients are computed using the index of SWX firms and of Nasdaq firms as market proxies, respectively. Consequently, our holdout firms have below-average risk in a relative sense. In other words, they are less risky than the average firm in their respective indexes. Given that the sample selection criteria weed out firms with negative earnings and firms with insufficient data (and hence riskier firms), this phenomenon should not be surprising. The return standard deviations (STDEV) suggest that Nasdaq firms are riskier than SWX firms, particularly during the second half of the sample period. Finally, the table documents that the representative Nasdaq firm has higher relative bid-ask spreads than the typical SWX firm, although mainly during the first half of the sample period.

\subsubsection{Regression results}

We first replicate the analysis in column (1) of Table 3 (not reported). The results are fairly similar to what we obtain there. In particular, whereas the coefficient associated with size (LNSIZE) is positive and significant in either sample, that of relative spread (RELSP) never has the predicted negative sign.

To distinguish between possible liquidity effects and size effects unrelated to liquidity, we then estimate the regression equation (6) with a robust estimation technique. The results are once again mostly consistent with those found for the original sample in Table 4. We report them in Table 7, subdivided in two panels: Panel A refers to SWX companies, Panel B to Nasdaq companies. As shown there, the regression has a significant F-value with confidence in excess of 0.99 in all years and samples. Moreover, its explanatory power is fairly large, especially in the SWX sample - the adjusted $\mathrm{R}^{2}$ is between $65 \%$ and $97 \%$ for SWX companies, and between $43 \%$ and $71 \%$ for Nasdaq companies. As for the regression coefficients, we find that 
higher expected earnings growth one and two years ahead (EPSg,t+1 and EPSg, $\mathrm{t}+2$, respectively) appears to significantly boost stock prices. More importantly, and consistent with the claim that lower liquidity reduces asset value, the relative bid-ask spread (RELSP) is negatively related to stock prices in both samples. This relation is statistically significant with confidence better than 0.99 . Furthermore, the residual of the regression of firm size against the relative bid-ask spread (RES-SIZE/RELSP) has a positive and significant coefficient in both samples as well. As mentioned above, larger (adjusted) firm size could reflect lower risk. Risk (BETA), however, has the expected negative coefficient only in the Swiss sample. In contrast, Nasdaq firms exhibit risk coefficients that are positive with confidence of at least 0.99 . Chalmers and Kadlec (1998) report a similar puzzling finding in their cross-sectional analysis of stock returns and liquidity. The coefficients on beta they find are negative and significant. ${ }^{15}$ The Chalmers and Kadlec sample covers U.S. domiciled common stocks listed on either the Amex or the NYSE during 1983-1992.

At the bottom of each panel, we examine the stationarity over time of the liquidity coefficients. The number shown is the t-value of a significance test of the change in that coefficient from one year to the next. The null hypothesis is that the change is zero. As one can see, almost all annual changes are significant with confidence 0.99 . The relevance of liquidity in asset pricing therefore appears to vary over time. This suggests that a cross-sectional analysis of the pricing relevance of liquidity of the type performed here can indeed be a valuable complement to the return-based approach since it yields up-to-date (as opposed to historical) measures of the impact of liquidity on asset prices. Note, however, that changes in liquidity coefficients do not necessarily imply changes in liquidity-related discounts in asset prices. The reason is that liquidity itself can change from one year to the other. A look back at the descriptive statistics in Table 6 reveals that bid-ask spreads do in fact change over time. For instance, on the Nasdaq, they have experienced a steady decline from an average $2.58 \%$ in 1995 to an average $1.01 \%$ in 2001 .

We repeat the analysis with a different measure of risk, namely the stock return variance as opposed to the stock's beta (not shown). The results are essentially the same as those we just examined, including those pertaining to the coefficient of

15 Eleswarapu and Reinganum (1993) report a consistent finding for a similar time period. 
risk. In the Swiss sample, higher return variance reduces stock prices. The opposite is true in the Nasdaq sample. It could be that higher return variance measures better growth opportunities. Since Nasdaq firms would seem to include more start-ups than the SWX firms, that could explain our finding. To check this interpretation, we include both measures of risk in the regression for Nasdaq firms. We expect a positive coefficient on return variance and a negative one on beta. Contrary to that, however, the coefficient on beta remains positive whereas that associated with return variance becomes generally negative (not shown).

As mentioned above, the bid-ask spread is not the only measure of liquidity one can think of. Trading volume, turnover, number of shareholders, and number of market makers, among others, have been proposed as alternative or additional measures in the literature. ${ }^{16}$ To test whether the price-spread relation uncovered above is indeed a price-liquidity relation, we repeat the analysis using trading volume as a measure of liquidity. Trading value is the average daily value traded in a particular stock over the past 2.5 years (the results do not change when we measure the average over the past 6 months). The results of this investigation are reported in Table 8. In the regression, we replace the relative bid-ask spread variable with the natural logarithm of trading volume (LNVOLUME). We also estimate the variable that gauges the net effect of firm size differently. As one might remember, that variable is the residual of a univariate regression of firm size against bid-ask spread. When the liquidity proxy is trading volume, we estimate that residual by regressing firm size (LNSIZE) against trading volume (LNVOLUME). We refer to the resulting residual as RES-SIZE/LNVOL. Since liquidity would seem to correlate positively with trading volume, we expect this liquidity proxy to have a positive coefficient.

The results confirm what we have found so far. The explanatory power of the regressions remains essentially unchanged. Furthermore, all regressors have significant coefficients with the sign observed in previous tables (except for the coefficient of the risk variable BETA that tends to become less significant in the SWX sample). Specifically, the coefficients of projected earnings growth (EPSgt +1 and EPSgt+2, respectively) and firm size (RES-SIZE/LNVOL) have a positive sign. Risk (BETA) has a negative sign in the SWX sample and a positive one in the Nasdaq

\footnotetext{
16 See, for instance, the discussion in Amihud und Mendelson (1986) and, especially, Baker (1996).
} 
sample. More importantly, the impact of higher liquidity on $\mathrm{P} / \mathrm{E}$ ratios (and therefore prices) remains positive: higher trading volume is associated with higher $\mathrm{P} / \mathrm{E}$ ratios. This is in line with the finding that larger relative spreads (and therefore lower liquidity) depress $\mathrm{P} / \mathrm{E}$ ratios (and therefore prices).

\subsection{Interpretation}

\subsubsection{Implied illiquidity discounts}

The last issue to address is ultimately the most important one: the economic significance of the results. The analysis so far reveals that liquidity appears to have a significant impact on $\mathrm{P} / \mathrm{E}$ ratios. Given that we control for various additional factors of influence, the coefficients of the liquidity proxies measure the marginal contribution of liquidity to the $\mathrm{P} / \mathrm{E}$ ratio of a given company. Since there is little theoretical reason to believe that market liquidity affects firm earnings, we have argued that this contribution involves prices rather than earnings. Various studies that find a positive relation between bid-ask spreads and historical stock returns support this interpretation.

To examine the economic significance of liquidity, we write the estimated regression equation (7) as:

$$
(\mathrm{P} / \mathrm{E})_{\mathrm{RELSP} \neq 0}=\exp \left(\begin{array}{l}
\hat{\alpha}_{0}+\hat{\alpha}_{1} \times \mathrm{EPSg} 2000+\hat{\alpha}_{2} \times \mathrm{EPSg} 2001+\hat{\alpha}_{3} \times \mathrm{BETA}+ \\
+\hat{\alpha}_{4} \times \mathrm{RES}-\mathrm{SIZE} / \mathrm{RELSP}+\hat{\alpha}_{5} \times \mathrm{RELSP}
\end{array}\right),
$$

where a hat denotes estimated coefficients, and we drop for simplicity the index $\mathrm{i}$.

The subscript RELSP $\neq 0$ indicates that this expression holds for the general case of a firm with limited liquidity, as measured by a bid-ask spread different from zero.

As a comparison, we can write the estimated $\mathrm{P} / \mathrm{E}$ ratio for a firm with perfect liquidity as:

$$
(\mathrm{P} / \mathrm{E})_{\mathrm{RELSP}=0}=\exp \left(\begin{array}{l}
\hat{\alpha}_{0}+\hat{\alpha}_{1} \times \mathrm{EPSg} 2000+\hat{\alpha}_{2} \times \mathrm{EPSg} 2001+\hat{\alpha}_{3} \times \mathrm{BETA}+ \\
+\hat{\alpha}_{4} \times \mathrm{RES}-\mathrm{SIZE} / \mathrm{RELSP}
\end{array}\right) .
$$


Taking the difference between equations (9) and (8) and dividing by equation (9) yields an expression for the estimated discount induced by limited liquidity, namely:

$$
\left(\frac{(\mathrm{P} / \mathrm{E})_{\mathrm{RELSP}=0}-(\mathrm{P} / \mathrm{E})_{\mathrm{RELSP} \neq 0}}{(\mathrm{P} / \mathrm{E})_{\mathrm{RELSP}=0}}\right)=1-\exp \left(\hat{\alpha}_{5} \times \mathrm{RELSP}\right) .
$$

Thus, to compute the pricing discount generated by a given degree of illiquidity, all we have to do is insert the appropriate bid-ask spread and the estimated coefficient $\hat{\alpha}_{5}$ in equation (10) above. For instance, for the particular case of firms with a bid-ask spread equal to the median spread in the original sample of SWX firms $($ RELSP $=1.37 \%$ in Table 1$)$, we obtain a point estimate of $1-\exp (-10.107 \times 0.0137)=12.93 \%$, where the computation uses the robust regression coefficient estimate $\hat{\alpha}_{5}$ reported in Table 4, namely -10.107 . The result says that, compared with a situation of perfect liquidity, the stock price of a firm with a bid-ask spread of $1.37 \%$ would trade at a $12.93 \%$ discount. To obtain an interval estimate, we find the $95 \%$ confidence interval for the coefficient estimate and insert it into equation (10). For our original sample, this interval is $(5.76 \%, 19.55 \%)$. Remember that these discounts are computed relative to a situation of perfect liquidity.

We can replicate this computation for the median firms in our holdout samples. Specifically, for each sample and each year, we take the median bid-ask spread and the liquidity coefficient reported in Table 7 for the year in question, and compute the illiquidity discount according to equation (10). The results are reported in Figure 2. As one can see, the median discount for SWX firms increases during the sample years from $7.3 \%$ to $21.1 \%$. In comparison, the median illiquidity discount among Nasdaq firms is more or less constant at about $27 \%$ during the same period.

To examine less liquid firms more closely, we compare the ten firms with the largest bid-ask spread with the ten with the smallest spread in the original sample of SWX firms. Table 9 provides statistical information for these firms. The median spread of the least liquid firms is about 26 times larger than that of the most liquid firms (4.016\% compared to $0.156 \%$ ), and in one case, AGEFI, the spread exceeds $6 \%$. Somewhat surprisingly, the least liquid firms are also less risky (median beta of 0.42 
vs. 1.13). ${ }^{17}$ Moreover, they are almost 1,000 times smaller (USD 54.1 million compared with USD 52.7 billion, assuming an exchange rate of CHF 1.4 to the dollar). To get a better sense for these equity capitalization numbers, consider that, on May 16, 2001, the distribution of Nasdaq firms by market value of equity was as follows:

\begin{tabular}{ccc}
\hline $\begin{array}{c}\text { Market capitalization (million } \\
\text { USD) }\end{array}$ & Number of firms & $\begin{array}{c}\text { Fraction of total market } \\
\text { capitalization }\end{array}$ \\
\hline $0-54.14$ & 1,858 & $1.07 \%$ \\
$54.14-100$ & 576 & $1.13 \%$ \\
$100-1,000$ & 1,513 & $13.63 \%$ \\
$1,000-5,000$ & 355 & $19.08 \%$ \\
$5,000-20,000$ & 97 & $23.79 \%$ \\
$20,000-50,000$ & 16 & $12.41 \%$ \\
50,000 plus & 9 & $28.89 \%$ \\
\hline Sum & 4,424 & $100.00 \%$ \\
\hline
\end{tabular}

With this distribution, the ten least liquid firms in our original sample would belong to the smallest $42 \%[=1,858 / 4,424]$ of the distribution of Nasdaq firms. In comparison, with a median capitalization of USD 52.7 billion, the most liquid firms would fall into the top $0.2 \%[=9 / 4,424]$ of that distribution. Thus the most liquid firms on the SWX are fairly large by U.S. standards also, whereas the least liquid firms would be small in either country. ${ }^{18}$

We can use our data to compute the illiquidity discount for these two extreme groups of firms. From equation (10) and the respective median bid-ask spreads of $4.016 \%$ and $0.156 \%$, we find that, in relation to perfect liquidity, the discount of the least liquid firms equals $33.4 \%[=1-\exp (-10.107 \times 0.04016)]$; in contrast, the most liquid firms sell at a $1.6 \%[=1-\exp (-10.107 \times 0.00156)]$ discount. The illiquidity

17 Since betas are estimated with monthly returns, infrequent trading cannot be the only reason for this result.

18 As one might remember, equity value is based only on the most liquid class of stock outstanding for firms with more than one class. This tends to reduce the market capitalization of Swiss firms in the comparison, although not by much. First, there are only 15 firms with multiple classes of stock outstanding in the original sample. And second, the market capitalization of the omitted classes is fairly small. 
discount of the least liquid companies is therefore sizable and should provide firms strong incentives for corrective action.

\subsubsection{Is the implied illiquidity discount reasonable?}

The illiquidity discount implied by our estimates appears to be substantial. To assess its magnitude, we can compare it to what the extant literature suggests. ${ }^{19}$ One possible benchmark is papers that investigate the relation between returns and liquidity, in particular the classical Amihud and Mendelson (1986) study of NYSE stocks. According to that paper, a 1\% increase in the relative spread is associated with an increase in expected return of $2.53 \%$. Taking into account that the relative spreads in the portfolios in that analysis range from $0.49 \%$ to $3.21 \%$, this figure implies an expected return differential of $6.88 \%$ between the portfolios with high and low spreads, respectively. ${ }^{20}$ If we consider a stock that pays a perpetual annual dividend of $\$ 1$, this return differential yields an illiquidity discount of roughly $58 \%$. The results in Brennan and Subrahmanyam (1996) ten years later are strikingly similar: the return differential between the most liquid and the least liquid quintiles of firms in their sample of NYSE firms is 662 basis points, which implies a similar illiquidity discount. Consequently, when taken at face value, the discount derived in these studies appears to be even larger than what we find here.

Another place to look for a comparison are studies of restricted stock sales, such as the private placement of a large block of stock with selected institutional investors (see Bajaj, Denis, Ferris, and Sarin, 2001). A comparison of the prices of publicly traded shares with the prices at which these issues are placed yields a possible measure of the illiquidity discount (see, for instance, Silber, 1991). According to Koeplin, Sarin, and Shapiro (2000), the mean and median discounts reported by these studies vary between $22 \%$ and $35 \%$, which would be consistent with what we find. The problem with these estimates is that they may be confounded by factors other than limited liquidity-for instance, the possible commitment by the block buyers to be active monitors. ${ }^{21}$

19 What follows is taken from Brennan and Tamarowski (2000), p. 35.

20 Practitioners in Switzerland recommend adding a limited liquidity premium of between 1\% and 3\% when capitalizing company cash flows (see the discussion in Helbling, 1989, and Boemle, 1995).

21 See the discussion in Koeplin, Sarin, and Shapiro (2000), p. 95. See also Hertzel and Smith (1993). 
Yet another place to potentially look for comparisons is block trades and seasoned stock offerings. ${ }^{22}$ The price impact of these transactions is presumably related to the liquidity of a given security. According to Keim and Madhavan (1996), for instance, seller-initiated trades have a permanent 1 -week impact of $-4.32 \%$ and a permanent 4-week impact of $-7.4 \%$. Unfortunately, it is difficult to relate these price changes to the illiquidity discounts already impounded in the price of these securities.

\section{Conclusions}

In this paper we examine whether the capital markets impose a discount when valuing firms with limited liquidity. We do so by looking directly at stock prices. Compared with other investigations that examine stock returns, this approach has the advantage of providing current rather than historical information. Moreover, it does not require as many data.

We originally perform the investigation with a cross-sectional regression with a sample of firms listed on the SWX in 2000. The correct specification is found partly on the basis of simple theoretical considerations, partly on the basis of what previous research has found, and partly on the basis of what a preliminary investigation suggests. After controlling for earnings growth, risk, and firm size (all of which play a significant role), we uncover a statistically significant and economically relevant relation between liquidity, as measured by the relative bid-ask spread of a given security, and stock prices. The same conclusion follows when we use trading volume as an alternative liquidity proxy.

We replicate the analysis with two control samples and obtain virtually the same results. The first covers the SWX in 1995-1999 and in 2001. The second covers the Nasdaq during 1995-2001. We use a robust least squares estimation approach to get around the problem of nonnormal regression residuals. The evidence suggests that the most liquid firms are valued with a moderate discount for limited liquidity (between $1 \%$ and 3\%), whereas the least liquid firms suffer a discount of about $30 \%$ (all point estimates).

\footnotetext{
22 See, among others, Saar, 2001, Cheng and Madhavan, 1997, Keim and Madhavan, 1996, Seppi, 1992, Loderer, Cooney, and Van Drunen, 1991, Ball and Finn, 1989, Holthausen, Leftwich, and Mayers, 1987, Mikkelson and Partch 1985.
} 


\section{References}

Amihud, Y., Mendelson, H., 2000. The liquidity route to a lower cost of capital. Journal of Applied Corporate Finance 12, 8-25.

Amihud, Y., Mendelson, H., 1986. Asset pricing and bid-ask spread. Journal of Financial Economics 17, 223-249.

Amihud, Y., Mendelson, H., Uno, J., 1999. Number of shareholders and share prices: Evidence from Japan. Journal of Finance 54, 1169-1184.

Amihud, Y., Mendelson, H., Lauterbach, B., 1997. Market microstructure and securities values: Evidence from the Tel Aviv Stock Exchange. Journal of Financial Economics 45, 365-390.

Bagwell, L.S., 1992. Dutch auction repurchases: An analysis of shareholder heterogeneity. Journal of Finance 47, 71-106.

Bajaj, M., Denis, D.J., Ferris, S.P., Sarin, A., 2001. Firm value and marketability discounts. Journal of Corporation Law 27, 89-115.

Baker, H.K., 1996. Trading location and liquidity: An analysis of U.S. dealer and agency markets for common stocks. Financial Markets, Institutions and Instruments 5.

Ball, R., Finn, F.J., 1989. The effect of block transactions on share prices: Australian evidence. Journal of Banking and Finance 13, 397-419.

Banz, R., 1981. The relationship between return and market value of common stocks. Journal of Financial Economics 9, 3-18.

Black, F., 1986. Noise. Journal of Finance 41, 529-543.

Boemle, M., 1995. Unternehmungsfinanzierung. SKV, Zürich.

Breen, W.J., Hodrick, L.S., Korajczyk, R.A, 2002. Predicting equity liquidity. Management Science 48, 470-483.

Brennan, M.J., Subrahmanyam, A., 1996. Market microstructure and asset pricing: On the compensation for illiquidity in stock returns. Journal of Financial Economics 41, $441-464$.

Brennan, M.J., Cordia, T., Subrahmanyam, A., 1998. Alternative factor specifications, security characteristics, and the cross-section of expected stock returns. Journal of Financial Economics 49, 345-373.

Brennan, M.J., Tamarowski, C., 2000. Investor relations, liquidity, and stock prices. Journal of Applied Corporate Finance 12, 26-37.

Chalmers, J.M.R., Kadlec, G.B., 1998. An empirical examination of the amortized spread. Journal of Financial Economics 48, 159-188. 
Chen, N., Kan, R., 1995. Expected returns and the bid-ask spread. In: Saitou, S., Sawaki, K., Kubota, K. (eds.), Modern Portfolio Theory and Applications. Center for Academic Societies, Osaka Japan, pp. 65-80.

Cheng, M., Madhavan, A., 1997. In search of liquidity: Block trades in the upstairs and downstairs markets. Review of Financial Studies 10, 175-203.

Datar, V.T., Naik , N.Y., Radcliffe, R., 1998. Liquidity and stock returns: An alternative test. Journal of Financial Markets 1, 205-219.

Easley, D., O’Hara, M, 2001. Microstructure and asset pricing. In: Constantinides, G., Harris, M., Stulz, R. M. (eds.), The Handbook of the Economics of Finance. Elsevier Science, forthcoming.

Easley, D., Hvidkjaer, S., O’Hara, M., 2002. Is information risk a determinant of asset returns? Journal of Finance 57, 2185-2221.

Eleswarapu, V.R., 1997. Cost of transacting and expected returns in the Nasdaq market. Journal of Finance 52, 2113-2127.

Eleswarapu, V.R., Reinganum, M., 1993. The seasonal behavior of the liquidity premium in asset pricing. Journal of Financial Economics 34, 373-386.

Engle, R.F., Patton, A.J., 2004. Impacts of trades in an error-correction model of quote prices. Journal of Financial Markets 7, 1-25.

Fama, E.F., 1996. Discounting under uncertainty. Journal of Business 69, 415-428.

Fama, E.F., French, K.R., 1993. Common risk factors in the return on stocks and bonds. Journal of Financial Economics 33, 3-56.

Galloway, T., Loderer, C., Sheehan, D., 1998. What does the market learn from stock offering revisions? Financial Management 27, 5-16.

Gardiol, L., Gibson-Asner, R., Tuchschmid, N., 1997. Are liquidity and corporate control priced by shareholders? Empirical evidence from the Swiss dual class shares. Journal of Corporate Finance 3, 299-323.

Glosten, L.R., Harris, L.E., 1988. Estimating the components of the bid/ask spread. Journal of Financial Economics 21, 123-142.

Grossman, S.J., Miller, M.H., 1988. Liquidity and market structure. Journal of Finance 43, 617-633.

Hamilton, L., 1992. Regression with graphics: A second course in applied statistics. Brooks/Cole, Belmont, California. 
Harris, L., Gurel, E., 1986. Price and volume effects associated with changes in the S\&P 500 list: New evidence for the existence of price pressures. Journal of Finance $41,815-829$.

Helbling, C., 1989. Unternehmensbewertung und Steuern. IdW, Düsseldorf.

Hertzel, M., Smith, R.L., 1993. Market discounts and shareholder gains for placing equity privately, Journal of Finance 48, 459-485.

Holthausen, R.W., Leftwich, R.W., Mayers, D., 1987. The effect of large block transactions on security prices. Journal of Financial Economics 19, 237-267.

Huang, R.D., Stoll, H.R., 1997. The components of the bid-ask spread: A general approach. Review of Financial Studies 10, 995-1034.

Jones, C.M., Lipson, M.L., 1999. Price impacts and quote adjustment on the Nasdaq and NYSE/Amex. Unpublished working paper. Graduate School of Business, Columbia University.

Judge, G.G., Hill, R.C., Griffiths, W.E., Lütkepohl, H., Lee, T., 1988. Introduction to the theory and practice of econometrics. Wiley, New York.

Keim, D., Madhavan, A., 1996. The upstairs market for large-block transactions: Analysis and measurement of price effects. Review of Financial Studies 9, 1-36.

Koeplin, J., Sarin, A., Shapiro, A.C., 2000. The private company discount. Journal of Applied Corporate Finance 4, 94-101.

Loderer, C., Cooney, J.W., Van Drunen, L.D., 1991. The price elasticity of demand for common stock. Journal of Finance 46, 621-651.

Loderer, C., Jacobs A., 1995. The Nestlé Crash. Journal of Financial Economics 37, 315-339.

Merton, R.C., 1982. A simple model of capital market equilibrium with incomplete information. Journal of Finance 42, 483-510.

Mikkelson, W.H., Partch, M.M., 1985. Stock price effects and costs of secondary distributions. Journal of Financial Economics 14, 165-194.

Saar, G., 2001. Price impact asymmetry of block trades: An institutional trading explanation. Review of Financial Studies 14, 1153-1181.

Seppi, D.J., 1992. Block trading and information revelation around quarterly earnings announcement. Review of Financial Studies 5, 281-305.

Shleifer, A., 1986. Do demand curves for stock slope down? Journal of Finance 41, 579-590. 
Shleifer, A., Vishny R.W., 1997. The limits of arbitrage. Journal of Finance 52, 3555 .

Silber, W.L., 1991. Discount on restricted stocks: The impact on illiquidity on stock prices. Financial Analyst Journal 47, 60-64.

Stoll, H.R., 2002. Market microstructure. In: Constantinides, G., Harris, M., Stulz, R. M. (eds.), The Handbook of the Economics of Finance. Elsevier Science, forthcoming.

Stulz, R.M., 1995a. International portfolio choice and asset pricing: An integrative survey. In: Robert A.J., Maksimovic V., Ziemba, W.T. (eds.), Handbook of Finance. North-Holland, Amsterdam, pp. 201-223.

Stulz, R.M., 1995b. The cost of capital in internationally integrated markets: The case of Nestlé. European Financial Management 1, 11-22.

Stulz, R.M., Wasserfallen, W., 1995. Foreign equity investment restrictions, capital flight, and shareholder wealth maximization: Theory and evidence. Review of Financial Studies 8, 1019-1057. 


\section{Table 1}

\section{Descriptive statistics for the original sample}

This table presents descriptive statistics for the variables in the cross-sectional regression analysis of the original sample.

\begin{tabular}{lcccccc}
\hline Variables & Sample size & Average & Median & Maximum & Minimum & $\begin{array}{c}\text { Standard } \\
\text { deviation }\end{array}$ \\
\hline P/E & 124 & 39.88 & 18.93 & $1,107.50$ & 5.71 & 106.32 \\
EPSg2000 & 124 & $63.0 \%$ & $14.4 \%$ & $2,497.5 \%$ & $-66.3 \%$ & $266.8 \%$ \\
EPSg2001 & 124 & $17.8 \%$ & $16.2 \%$ & $68.0 \%$ & $-19.7 \%$ & $12.5 \%$ \\
PAYOUT & 124 & $35.2 \%$ & $28.7 \%$ & $479.5 \%$ & $0.0 \%$ & $48.1 \%$ \\
BETA & 124 & 0.735 & 0.691 & 1.830 & -0.518 & 0.429 \\
STDEV & 124 & $45.91 \%$ & $32.77 \%$ & $353.38 \%$ & $12.31 \%$ & $47.26 \%$ \\
SIZE & 124 & 8,327 & 1,027 & 186,384 & 28 & 26,022 \\
RELSP & 124 & $1.68 \%$ & $1.37 \%$ & $12.22 \%$ & $0.09 \%$ & $1.54 \%$ \\
\hline
\end{tabular}

\begin{tabular}{|c|c|}
\hline Variable definitions & \\
\hline $\mathrm{P} / \mathrm{E}$ & $\begin{array}{l}\text { Price-earnings ratio. The stock price }(\mathrm{P}) \text { is the one observed on June } 30,2000 . \\
\text { The earnings-per-share figure }(\mathrm{E}) \text { refers to } 1999 \text {; }\end{array}$ \\
\hline EPSg2000 & $\begin{array}{l}\text { Projected earnings growth between } 1999 \text { and } 2000 \text {. This variable is inferred } \\
\text { from the average EPS predictions by financial analysts as reported on June } 30 \text {, } \\
2000 \text { for the year 2000; }\end{array}$ \\
\hline EPSg2001 & $\begin{array}{l}\text { Projected earnings growth between } 2000 \text { and } 2001 \text {. This variable is inferred } \\
\text { from the average EPS predictions by financial analysts as reported on June } 30 \text {, } \\
2000 \text { for the year 2001; }\end{array}$ \\
\hline PAYOUT & $\begin{array}{l}\text { Payout ratio, defined as the ratio of dividends paid out in } 1999 \text { on the stock in } \\
\text { question divided by earnings per share during the same year; }\end{array}$ \\
\hline BETA & $\begin{array}{l}\text { Beta of the stock in question. This variable is computed with a market model } \\
\text { and monthly data during the period 1.1.1997 to } 6.30 .2000 \text {; }\end{array}$ \\
\hline STDEV & $\begin{array}{l}\text { Annualized standard deviation of monthly stock returns during the period } \\
\text { 1.1.1997 to } 6.30 .2000 \text {; }\end{array}$ \\
\hline SIZE & $\begin{array}{l}\text { Market capitalization in million Swiss Francs of the most liquid class of stock } \\
\text { of the firm under analysis. This variable is computed as an average of six } \\
\text { monthly observations during the period } 1.1 .2000 \text { to } 6.30 .2000 \text {; }\end{array}$ \\
\hline RELSP & $\begin{array}{l}\text { Relative bid-ask spread, defined as the ratio of the difference between ask and } \\
\text { bid prices, divided by bid price. The spread is calculated as an average of two } \\
\text { daily observations (at } 10 \text { a.m. and } 4 \text { p.m.) during the period } 1.1 .1997 \text { to } \\
6.30 .2000 \text {. }\end{array}$ \\
\hline
\end{tabular}


Table 2

Stock prices and bid-ask spread: preliminary OLS regression estimates

The dependent variable is the P/E ratio of firms listed on the SWX Swiss Exchange. The day of reference for the cross-sectional regression is June 30, 2000.

\begin{tabular}{lccc}
\hline & Regression coefficient & t-statistics & $p$-values \\
\hline Intercept & 17.006 & 2.272 & 0.025 \\
EPSg2000 & 36.426 & 27.306 & 0.000 \\
EPSg2001 & 89.025 & 2.930 & 0.004 \\
RELSP & $-1,320.395$ & -2.658 & 0.009 \\
RELSP & $12,039.68$ & 2.289 & 0.024 \\
& & & \\
Number of observations & 124 & & \\
F-statistic (p-value) & $198.00(0.000)$ & & \\
Adjusted R-square & 0.865 & & \\
\hline
\end{tabular}

\begin{tabular}{|c|c|}
\hline Variable definitions & \\
\hline $\mathrm{P} / \mathrm{E}$ & $\begin{array}{l}\text { Price-earnings ratio. The stock price }(\mathrm{P}) \text { is the one observed on June } 30 \text {, } \\
\text { 2000. The earnings-per-share figure }(\mathrm{E}) \text { refers to } 1999 \text {; }\end{array}$ \\
\hline EPSg2000 & $\begin{array}{l}\text { Projected earnings growth between } 1999 \text { and } 2000 \text {. This variable is inferred } \\
\text { from the average EPS predictions by financial analysts as reported on June } \\
30,2000 \text { for the year 2000; }\end{array}$ \\
\hline EPSg2001 & $\begin{array}{l}\text { Projected earnings growth between } 2000 \text { and } 2001 \text {. This variable is inferred } \\
\text { from the average EPS predictions by financial analysts as reported on June } \\
30,2000 \text { for the year 2001; }\end{array}$ \\
\hline RELSP & $\begin{array}{l}\text { Relative bid-ask spread, defined as the ratio of the difference between ask } \\
\text { and bid prices, divided by bid price. The spread is calculated as an average } \\
\text { of two daily observations (at } 10 \text { a.m. and } 4 \text { p.m.) during the period } 1.1 .1997 \\
\text { to } 6.30 .2000 \text {; }\end{array}$ \\
\hline RELSP $^{2}$ & Squared value of the relative bid-ask spread. \\
\hline
\end{tabular}


Table 3

\section{Stock prices and relative bid-ask spread: OLS regression estimates (original sample)}

The dependent variable is the natural logarithm of the P/E ratio of firms listed on the SWX Swiss Exchange. Each column reports the estimated regression coefficients for one particular specification and (in parentheses) the associated p-value (on the basis of White-corrected standard errors) for a two-sided test of difference from zero. The day of reference for the cross-sectional regression is June 30, 2000.

\begin{tabular}{lcc}
\hline \multicolumn{1}{c}{ Independent variables } & \multicolumn{1}{c}{ Regression coefficients } & $(2)$ \\
\hline \multirow{2}{*}{ Intercept } & 2.036 & 2.988 \\
& $(0.000)$ & $(0.000)$ \\
EPSg2000 & 0.369 & 0.287 \\
& $(0.000)$ & $(0.000)$ \\
EPSg2001 & 2.363 & 2.605 \\
PAYOUT & $(0.000)$ & $(0.000)$ \\
& -0.090 & \\
BETA & $(0.000)$ & -0.280 \\
& -0.266 & $(0.099)$ \\
LNSIZE & $(0.007)$ & \\
& 0.114 & 0.114 \\
RES-SIZE/RELSP & $(0.000)$ & $(0.020)$ \\
RELSP & & -18.077 \\
& -6.101 & $(3.604)$ \\
Number of observations & $(0.194)$ & 122 \\
F-statistic & & $22.94(0.000)$ \\
Adjusted R-squared & 122 & 0.627 \\
\hline
\end{tabular}

\begin{tabular}{|c|c|}
\hline Variable definitions & \\
\hline $\mathrm{P} / \mathrm{E}$ & $\begin{array}{l}\text { Price-earnings ratio. The stock price }(\mathrm{P}) \text { is the one observed on June } 30 \text {, } \\
\text { 2000. The earnings-per-share figure }(\mathrm{E}) \text { refers to } 1999 \text {; }\end{array}$ \\
\hline $\ln (\mathrm{P} / \mathrm{E})$ & Natural logarithm of P/E; \\
\hline EPSg2000 & $\begin{array}{l}\text { Projected earnings growth between } 1999 \text { and } 2000 \text {. This variable is inferred } \\
\text { from the average EPS predictions by financial analysts as reported on June } \\
30,2000 \text { for the year 2000; }\end{array}$ \\
\hline EPSg2001 & $\begin{array}{l}\text { Projected earnings growth between } 2000 \text { and } 2001 \text {. This variable is inferred } \\
\text { from the average EPS predictions by financial analysts as reported on June } \\
30,2000 \text { for the year 2001; }\end{array}$ \\
\hline PAYOUT & $\begin{array}{l}\text { Payout ratio, defined as the ratio of dividends paid out in } 1999 \text { on the stock in } \\
\text { question divided by earnings per share during the same year; }\end{array}$ \\
\hline BETA & $\begin{array}{l}\text { Beta of the stock in question. This variable is computed with a market model } \\
\text { and monthly data during the period } 1.1 .1997 \text { to } 6.30 .2000 \text {; }\end{array}$ \\
\hline LNSIZE & $\begin{array}{l}\text { Natural logarithm of the market capitalization of the most liquid stock (SIZE) } \\
\text { of the firm under analysis. The variable SIZE is computed as an average of } \\
\text { six monthly observations during the period } 1.1 .2000 \text { to } 6.30 .2000 \text {; }\end{array}$ \\
\hline RES-SIZE/RELSP & $\begin{array}{l}\text { Residual of a regression of LNSIZE against RELSP. The estimation period } \\
\text { is } 1.1 .1997 \text { to } 6.30 .2000 \text {. LNSIZE is the natural logarithm of the market } \\
\text { capitalization of the most liquid class of stock (SIZE) of the firm under } \\
\text { analysis. The variable SIZE is computed as an average of six monthly } \\
\text { observations during the period 1.1.2000 to } 6.30 .2000 \text {; }\end{array}$ \\
\hline RELSP & $\begin{array}{l}\text { Relative bid-ask spread, defined as the ratio of the difference between ask } \\
\text { and bid prices, divided by bid price. The spread is calculated as an average } \\
\text { of two daily observations (at } 10 \text { a.m. and } 4 \text { p.m.) during the period } 1.1 .1997 \\
\text { to } 6.30 .2000 \text {. }\end{array}$ \\
\hline
\end{tabular}




\section{Figure 1}

Kernel density estimate versus theoretical normal density of the regression residuals (original sample)

The dotted line in the graph shows the kernel density estimate of the residuals from the regression estimates in the second column of Table 3 . The continuous line shows the theoretical density if the residuals were normally distributed.

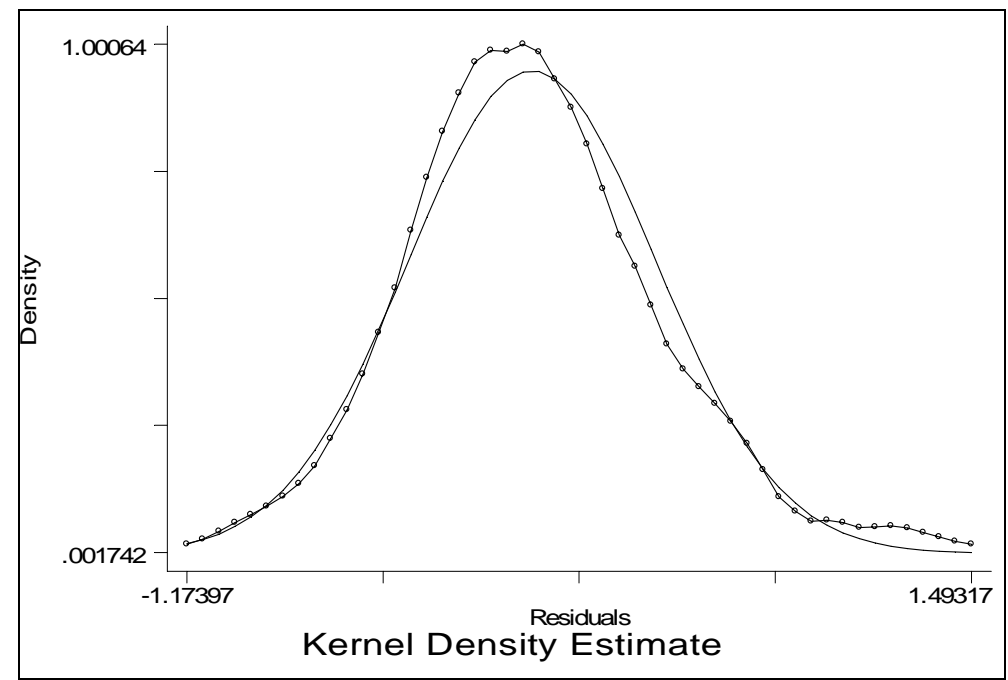




\section{Table 4}

\section{Stock prices and relative bid-ask spread: robust regression estimates (original sample)}

The dependent variable is the natural logarithm of the P/E ratio of firms listed on the SWX Swiss Exchange. Numbers in parentheses are t-statistics. The regressions are estimated with the Huber and Tukey algorithms. The day of reference for the cross-sectional regression for the original sample is June 30, 2000.

\begin{tabular}{lc}
\hline & $\begin{array}{c}\text { Regression coefficients } \\
(t \text {-statistics })\end{array}$ \\
\hline Intercept & 2.916 \\
& $(25.740)$ \\
EPSg2000 & 0.288 \\
& $(10.926)$ \\
EPSg2001 & 1.838 \\
BETA & $(5.852)$ \\
& -0.229 \\
RES-SIZE/RELSP & $(-2.376)$ \\
RELSP & 0.143 \\
& $(4.501)$ \\
Number of observations & -10.107 \\
F-statistic (p-value) & $(-3.467)$ \\
\hline
\end{tabular}

Variable definitions

$\ln (\mathrm{P} / \mathrm{E}) \quad$ Natural logarithm of $\mathrm{P} / \mathrm{E}$, the price-earnings ratio. The stock price $(\mathrm{P})$ is the one observed on June 30, 2000 for the original sample and June 19, 2001 for the holdout sample. The earnings-per-share figure (E) refers to 1999;

EPSg2000

Projected earnings growth between 1999 and 2000. This variable is inferred from the average EPS predictions by financial analysts as reported on June 30, 2000 for the year 2000;

EPSg2001 Projected earnings growth between 2000 and 2001. This variable is inferred from the average EPS predictions by financial analysts as reported on June 30, 2000 for the year 2001;

BETA Beta of the stock in question. This variable is computed with a market model and monthly data during the period 1.1.1997 to 30.6.2000;

RELSP Relative bid-ask spread, defined as the ratio of the difference between ask and bid prices, divided by bid price. The spread is calculated as an average of two daily observations (at 10 a.m. and 4 p.m.) during the period 1.1.1997 to 6.30.2000;

RES-SIZE/RELSP Residual of a regression of LNSIZE against RELSP. The estimation period is 1.1.1997 to 6.30.2000. LNSIZE is the natural logarithm of the market capitalization of the most liquid class of stock (SIZE) of the firm under analysis. The variable SIZE is computed as an average of six monthly observations during the period 1.1.2000 to 6.30.2000; 
Table 5

Selection criteria and size of the holdout samples: SWX Swiss Exchange and Nasdaq firms

To be included in the sample, firms have to be included in the I/B/E/S files and have to report positive earnings for the year in question. Moreover, they have to have sufficient bid-ask spread and stockreturn data. Bid-ask spreads are computed as daily averages over the past 2.5 years; we require 600 of the possible 625 daily observations to include a particular firm in the sample. Betas are computed with monthly returns over the past 4.5 years; we require 50 of the possible 54 monthly observations to include a particular firm in the sample. Missing values can occur by chance or because a firm is not quoted during the full period.

Panel A: SWX Swiss Exchange firms

\begin{tabular}{lccccccc}
\hline & 1995 & 1996 & 1997 & 1998 & 1999 & 2000 & 2001 \\
\hline Total firms on the SWX & 215 & 213 & 216 & 231 & 239 & 250 & 256 \\
Firms with I/B/E/S coverage & 153 & 157 & 157 & 150 & 151 & 147 & 164 \\
$\quad$ with positive earnings & 118 & 127 & 137 & 140 & 141 & 132 & 124 \\
$\quad$ with sufficient bid-ask spread data & 118 & 127 & 137 & 140 & 140 & 128 & 119 \\
$\quad$ with sufficient stock-return data & 115 & 120 & 122 & 119 & 113 & 128 & 119 \\
\hline
\end{tabular}

Panel B: Nasdaq firms

\begin{tabular}{lccccccc}
\hline & 1995 & 1996 & 1997 & 1998 & 1999 & 2000 & 2001 \\
\hline $\begin{array}{l}\text { Total firms from CRSP tapes at the end of } \\
\text { June }\end{array}$ & 4,380 & 4,817 & 4,963 & 4,994 & 4,487 & 4,478 & 3,936 \\
Firms with I/B/E/S coverage & 3,143 & 3,570 & 3,981 & 4,034 & 3,903 & 3,663 & 3,214 \\
$\quad$ with positive earnings & 2,670 & 2,882 & 3,106 & 3,124 & 2,831 & 2,463 & 1,888 \\
$\quad$ with sufficient bid-ask spread data & 728 & 838 & 867 & 878 & 816 & 705 & 528 \\
$\quad$ with sufficient stock-return data & 513 & 586 & 628 & 664 & 577 & 548 & 450 \\
\hline
\end{tabular}


Table 6

\section{Descriptive statistics for the holdout samples}

This table presents the median values of the variables in the holdout samples (1995-2001). The day of reference is the last day of June of the year in question. For comparison purposes, Panel A includes the year 2000 with the original sample of SWX Swiss Exchange firms.

Panel A: SWX Swiss Exchange firms

\begin{tabular}{lccccccc}
\hline & 1995 & 1996 & 1997 & 1998 & 1999 & 2000 & 2001 \\
\hline P/E & 17.12 & 16.21 & 20.28 & 20.70 & 16.90 & 18.93 & 15.22 \\
EPSg,t+1 & $19.8 \%$ & $12.3 \%$ & $14.0 \%$ & $13.3 \%$ & $9.3 \%$ & $14.4 \%$ & $10.9 \%$ \\
EPSg,t+2 & $12.9 \%$ & $12.1 \%$ & $12.8 \%$ & $12.7 \%$ & $12.4 \%$ & $16.2 \%$ & $14.2 \%$ \\
BETA & 0.851 & 0.771 & 0.742 & 0.691 & 0.727 & 0.691 & 0.641 \\
STDEV & $28.47 \%$ & $25.11 \%$ & $25.95 \%$ & $25.77 \%$ & $28.82 \%$ & $32.77 \%$ & $29.86 \%$ \\
SIZE & 251 & 331 & 347 & 546 & 440 & 1,027 & 1,110 \\
RELSP & $1.74 \%$ & $1.41 \%$ & $1.25 \%$ & $1.21 \%$ & $1.48 \%$ & $1.37 \%$ & $1.26 \%$ \\
\hline
\end{tabular}

Panel B: Nasdaq firms

\begin{tabular}{lccccccc}
\hline & 1995 & 1996 & 1997 & 1998 & 1999 & 2000 & 2001 \\
\hline P/E & 22.67 & 24.66 & 25.74 & 24.19 & 21.28 & 19.60 & 20.22 \\
EPSg,t+1 & $12.3 \%$ & $12.2 \%$ & $14.4 \%$ & $12.7 \%$ & $13.1 \%$ & $15.8 \%$ & $7.8 \%$ \\
EPSg,t+2 & $17.1 \%$ & $17.4 \%$ & $18.2 \%$ & $18.7 \%$ & $17.2 \%$ & $19.2 \%$ & $17.7 \%$ \\
BETA & 0.817 & 0.822 & 0.716 & 0.700 & 0.648 & 0.530 & 0.345 \\
STDEV & $33.15 \%$ & $33.53 \%$ & $36.37 \%$ & $39.18 \%$ & $44.55 \%$ & $53.80 \%$ & $54.70 \%$ \\
SIZE & 247 & 287 & 300 & 325 & 314 & 422 & 445 \\
RELSP & $2.58 \%$ & $2.54 \%$ & $2.43 \%$ & $2.11 \%$ & $1.72 \%$ & $1.20 \%$ & $1.01 \%$ \\
\hline
\end{tabular}

\begin{tabular}{ll}
\hline Variable definitions & \\
\hline $\mathrm{P} / \mathrm{E}$ & $\begin{array}{l}\text { Price-earnings ratio. The stock price }(\mathrm{P}) \text { is the one observed at the end of June } \\
\text { for the year in question. The earnings-per-share figure (E) is the most recent } \\
\text { information for the year in question; } \\
\text { Projected earnings growth between } \mathrm{t} \text { and } \mathrm{t}+1 \text {. This variable is inferred from } \\
\text { the average earnings-per-share (EPS) predictions by financial analysts as } \\
\text { reported in the month of June; } \\
\text { Projected earnings growth between } \mathrm{t}+1 \text { and } \mathrm{t}+2 . \text { This variable is inferred from } \\
\text { the average earnings-per-share (EPS) predictions by financial analysts as } \\
\text { reported in the month of June; } \\
\text { Beta of the stock in question. This variable is computed with a market model } \\
\text { and monthly data during the past } 4.5 \text { years. The market index for the SWX } \\
\text { firms (Panel A) is the Swiss Performance Index (SPI) and the Nasdaq } \\
\text { Composite Index for the Nasdaq firms (Panel B); } \\
\text { Annualized standard deviation of monthly stock returns during the past } \\
\text { 4.5 years; } \\
\text { Market capitalization in million Swiss Francs for the SWX companies and in } \\
\text { million US Dollars for the Nasdaq companies. This variable is computed as } \\
\text { an average of the past six monthly observations; } \\
\text { Relative bid-ask spread, defined as the ratio of the difference between ask and } \\
\text { bid price, divided by bid price. The spread is calculated as an average of daily } \\
\text { closing observations during the past } 2.5 \text { years. }\end{array}$ \\
\hline RELSP &
\end{tabular}




\section{Table 7}

\section{Stock prices and relative bid-ask spread: robust regression coefficient estimates (holdout samples)}

The dependent variable is the natural logarithm of the $\mathrm{P} / \mathrm{E}$ ratio. One asterisk indicates probability values smaller than 0.05 ; two asterisks indicate probability values smaller than 0.01 ; and three asterisks indicate probability values smaller than 0.001 . The sample period is 1995-2001. The day of reference is the last day of month June for the year in question.

Panel A: SWX Swiss Exchange firms

\begin{tabular}{|c|c|c|c|c|c|c|c|}
\hline & 1995 & 1996 & 1997 & 1998 & 1999 & 2000 & 2001 \\
\hline Intercept & $2.644 * * *$ & $2.585 * * *$ & $2.770 * * *$ & $2.803 * * *$ & $3.042 * * *$ & $2.916 * * *$ & $2.952 * * *$ \\
\hline $\mathrm{EPSg}, \mathrm{t}+1$ & $0.984 * * *$ & $0.942 * * *$ & $1.042 * * *$ & $1.140 * * *$ & $1.244 * * *$ & $0.288 * * *$ & $0.379 * * *$ \\
\hline EPSg,t+2 & $1.269 * * *$ & $1.351 * * *$ & $0.901 * * *$ & $1.790 * * *$ & $1.016 * * *$ & $1.838 * * *$ & $0.414 * *$ \\
\hline BETA & $-0.171^{*}$ & -0.061 & -0.115 & -0.127 & $-0.407 * * *$ & $-0.229 *$ & $-0.262 * *$ \\
\hline $\begin{array}{l}\text { RES- } \\
\text { SIZE/RELSP }\end{array}$ & $0.072 * * *$ & $0.076 * * *$ & $0.104 * * *$ & $0.094 * * *$ & $0.135 * * *$ & $0.143 * * *$ & $0.146 * * *$ \\
\hline RELSP & $-4.330 * * *$ & $-5.292 * * *$ & $-5.273 * * *$ & $-10.596 * * *$ & $-16.164 * * *$ & $-10.107 * * *$ & $-13.147^{* * *}$ \\
\hline $\begin{array}{l}\text { Number of } \\
\text { observations }\end{array}$ & 114 & 119 & 118 & 117 & 111 & 123 & 115 \\
\hline $\begin{array}{l}\text { F-statistic } \\
\text { (p-value) }\end{array}$ & $\begin{array}{c}830.730 \\
(0.000)\end{array}$ & $\begin{array}{l}94.235 \\
(0.000)\end{array}$ & $\begin{array}{l}134.117 \\
(0.000)\end{array}$ & $\begin{array}{l}77.937 \\
(0.000)\end{array}$ & $\begin{array}{l}58.126 \\
(0.000)\end{array}$ & $\begin{array}{l}36.800 \\
(0.000)\end{array}$ & $\begin{array}{l}30.104 \\
(0.000)\end{array}$ \\
\hline $\begin{array}{l}\text { Adjusted } \\
\text { R-squared }\end{array}$ & 0.973 & 0.798 & 0.850 & 0.768 & 0.722 & 0.595 & 0.561 \\
\hline \multicolumn{2}{|c|}{$\begin{array}{l}\text { t-test of equality of the } \\
\text { coefficient of RELSP } \\
\text { (relative to previous year) }\end{array}$} & $-11.082 * * *$ & -0.038 & $9.995 * * *$ & $-41.130 * * *$ & $-6.800 * * *$ & $9.479 * * *$ \\
\hline
\end{tabular}

Panel B: Nasdaq firms

\begin{tabular}{|c|c|c|c|c|c|c|c|}
\hline & 1995 & 1996 & 1997 & 1998 & 1999 & 2000 & 2001 \\
\hline Intercept & $2.989 * * *$ & $3.155 * * *$ & $3.277 * * *$ & $3.176^{* * *}$ & $2.941 * * *$ & $2.913 * * *$ & $3.058 * * *$ \\
\hline EPSg,t+1 & $0.809 * * *$ & $0.851 * * *$ & $0.840 * * *$ & $0.908 * * *$ & $0.865 * * *$ & $1.025 * * *$ & $1.002 * * *$ \\
\hline EPSg, $\mathrm{t}+2$ & $1.161 * * *$ & $0.948 * * *$ & $0.903 * * *$ & $1.069 * * *$ & $1.424 * * *$ & $1.012 * * *$ & $1.095 * * *$ \\
\hline BETA & $0.341 * * *$ & $0.132 * * *$ & $0.152 * * *$ & $0.076 * * *$ & $0.215 * * *$ & $0.482 * * *$ & $0.298 * * *$ \\
\hline $\begin{array}{l}\text { RES- } \\
\text { SIZE/RELSP }\end{array}$ & $0.302 * * *$ & $0.287 * * *$ & $0.303 * * *$ & $0.250 * * *$ & $0.298 * * *$ & $0.356^{* * *}$ & $0.186^{* * *}$ \\
\hline RELSP & $-12.048 * * *$ & $-11.396^{* * *}$ & $-14.614 * * *$ & $-14.754 * * *$ & $-20.485^{* * *}$ & $-33.398 * * *$ & $-32.282 * * *$ \\
\hline $\begin{array}{l}\text { Number of } \\
\text { observations }\end{array}$ & 505 & 576 & 617 & 662 & 572 & 543 & 443 \\
\hline $\begin{array}{l}\text { F-statistic } \\
\text { (p-value) }\end{array}$ & $\begin{array}{l}78.031 \\
(0.000)\end{array}$ & $\begin{array}{c}113.194 \\
(0.000)\end{array}$ & $\begin{array}{l}132.593 \\
(0.000)\end{array}$ & $\begin{array}{l}166.175 \\
(0.000)\end{array}$ & $\begin{array}{c}182.880 \\
(0.000)\end{array}$ & $\begin{array}{c}270.371 \\
(0.000)\end{array}$ & $\begin{array}{l}179.447 \\
(0.000)\end{array}$ \\
\hline $\begin{array}{l}\text { Adjusted } \\
\text { R-squared }\end{array}$ & 0.433 & 0.494 & 0.516 & 0.555 & 0.614 & 0.713 & 0.669 \\
\hline \multicolumn{2}{|c|}{$\begin{array}{l}\text { t-test of equality of the } \\
\text { coefficient of RELSP } \\
\text { (relative to previous year) }\end{array}$} & 1.6151 & $-3,246.852 *$ * & $2.021^{*}$ & $11.985^{* * *}$ & $17.960 * * *$ & $6.351 * * *$ \\
\hline
\end{tabular}


Price-earnings ratio. The stock price $(\mathrm{P})$ is the one observed at the end of June for

information for the year in question;

EPSg, $t+1$

EPSg,t+2

LNSIZE

RELSP
Natural logarithm of P/E;

Projected earnings growth between $t$ and $t+1$. This variable is inferred from the average earnings-per-share (EPS) predictions by financial analysts as reported in the month of June;

Projected earnings growth between $t+1$ and $t+2$. This variable is inferred from the average earnings-per-share (EPS) predictions by financial analysts as reported in the month of June;

Beta of the stock in question. This variable is computed with a market model and monthly data during the past 4.5 years. The market index for the SWX firms (Panel A) is the Swiss Performance Index (SPI) and the Nasdaq Composite Index for the Nasdaq firms (Panel B);

Natural logarithm of the market value of equity of the company under consideration, computed as an average of the past six monthly observations;

Relative bid-ask spread, defined as the ratio of the difference between ask and bid price, divided by bid price. The spread is calculated as an average of daily closing observations during the past 2.5 years; 
Table 8

Stock prices and alternative liquidity measures: robust regression coefficient estimates (holdout samples)

The dependent variable is the natural logarithm of the $\mathrm{P} / \mathrm{E}$ ratio. One asterisk indicates probability values smaller than 0.05 ; two asterisks indicate probability values smaller than 0.01 ; and three asterisks indicate probability values smaller than 0.001. The sample period is 1995-2001. The day of reference is the last day of month June for the year in question.

Panel A: SWX Swiss Exchange Firms

\begin{tabular}{lccccccc}
\hline & 1995 & 1996 & 1997 & 1998 & 1999 & 2000 & 2001 \\
\hline Intercept & $1.692^{* * *}$ & $1.708^{* * *}$ & $1.585^{* * *}$ & $1.433^{* * *}$ & $1.225^{* * *}$ & $1.363^{* * *}$ & $1.647^{* * *}$ \\
EPSg,t+1 & $0.990^{* * *}$ & $0.945^{* * *}$ & $1.054^{* * *}$ & $1.136^{* * *}$ & $1.218^{* * *}$ & $0.305^{* * *}$ & $0.404^{* * *}$ \\
EPSg,t+2 & $1.297 * * *$ & $1.387^{* * *}$ & $0.857^{* * *}$ & $1.918^{* * *}$ & $0.966^{* * *}$ & $1.932^{* * *}$ & $0.449^{* * *}$ \\
BETA & -0.099 & -0.012 & -0.096 & -0.100 & $-0.345^{*}$ & $-0.212^{*}$ & $-0.213^{*}$ \\
RES- & $0.102 * * *$ & $0.141^{* * *}$ & $0.099^{* * *}$ & $0.135^{* * *}$ & $0.170^{* * *}$ & $0.178^{* *}$ & $0.205^{* * *}$ \\
$\begin{array}{l}\text { SIZE/LNVOL } \\
\text { LNVOLUME }\end{array}$ & $0.058^{* * *}$ & $0.054^{* * *}$ & $0.081^{* * *}$ & $0.085^{* * *}$ & $0.109^{* * *}$ & $0.095^{* * *}$ & $0.076^{* * *}$ \\
& & & & & & & \\
$\begin{array}{l}\text { Number of } \\
\text { observations }\end{array}$ & 114 & 118 & 118 & 117 & 112 & 123 & 115 \\
$\begin{array}{l}\text { F-statistic } \\
\text { (p-value) }\end{array}$ & $1,013.180$ & 112.528 & 132.889 & 74.136 & 56.102 & 40.943 & 32.041 \\
$\begin{array}{l}\text { Adjusted } \\
\text { R-squared }\end{array}$ & $(0.000)$ & $(0.000)$ & $(0.000)$ & $(0.000)$ & $(0.000)$ & $(0.000)$ & $(0.000)$ \\
\hline
\end{tabular}

Panel B: Nasdaq Firms

\begin{tabular}{lccccccc}
\hline & 1995 & 1996 & 1997 & 1998 & 1999 & 2000 & 2001 \\
\hline Intercept & $0.916^{* * *}$ & $1.165^{* * *}$ & $1.056^{* * *}$ & $1.126^{* * *}$ & $0.642^{* * *}$ & -0.380 & $0.448^{*}$ \\
EPSg,t+1 & $0.825^{* * *}$ & $0.864^{* * *}$ & $0.864^{* * *}$ & $0.921^{* * *}$ & $0.881 * * *$ & $1.013^{* * *}$ & $0.996^{* * *}$ \\
EPSg,t+2 & $1.260^{* * *}$ & $1.047^{* * *}$ & $0.975^{* * *}$ & $1.135^{* * *}$ & $1.507 * * *$ & $1.070^{* * *}$ & $1.089^{* * *}$ \\
BETA & $0.430^{* * *}$ & $0.204 * * *$ & $0.218^{* * *}$ & $0.146^{* *}$ & $0.328^{* * *}$ & $0.622^{* * *}$ & $0.245^{* * *}$ \\
RES- & $0.341^{* * *}$ & $0.339^{* * *}$ & $0.347^{* * *}$ & $0.301 * * *$ & $0.373 * * *$ & $0.473^{* * *}$ & $0.169^{* * *}$ \\
$\begin{array}{l}\text { SIZE/LNVOL } \\
\text { LNVOLUME }\end{array}$ & $0.117^{* * *}$ & $0.113^{* * *}$ & $0.125^{* * *}$ & $0.115^{* * *}$ & $0.127 * * *$ & $0.185^{* * *}$ & $0.152^{* * *}$ \\
& & & & & & & \\
$\begin{array}{l}\text { Number of } \\
\text { observations }\end{array}$ & 506 & 576 & 617 & 662 & 572 & 544 & 444 \\
$\begin{array}{l}\text { F-statistic } \\
\text { (p-value) }\end{array}$ & 80.286 & 114.054 & 134.676 & 172.545 & 189.679 & 280.657 & 176.636 \\
$\begin{array}{l}\text { Adjusted } \\
\text { R-squared }\end{array}$ & $(0.000)$ & $(0.000)$ & $(0.000)$ & $(0.000)$ & $(0.000)$ & $(0.000)$ & $(0.000)$ \\
\hline
\end{tabular}




\begin{tabular}{|c|c|}
\hline Variable definitions & \\
\hline $\mathrm{P} / \mathrm{E}$ & $\begin{array}{l}\text { Price-earnings ratio. The stock price }(\mathrm{P}) \text { is the one observed at the end of June for } \\
\text { the year in question. The earnings-per-share figure }(\mathrm{E}) \text { is the most recent } \\
\text { information for the year in question; }\end{array}$ \\
\hline $\ln (\mathrm{P} / \mathrm{E})$ & Natural logarithm of $\mathrm{P} / \mathrm{E}$ \\
\hline EPSg, $\mathrm{t}+1$ & $\begin{array}{l}\text { Projected earnings growth between } t \text { and } t+1 \text {. This variable is inferred from the } \\
\text { average earnings-per-share (EPS) predictions by financial analysts as reported in } \\
\text { the month of June; }\end{array}$ \\
\hline EPSg, $\mathrm{t}+2$ & $\begin{array}{l}\text { Projected earnings growth between } \mathrm{t}+1 \text { and } \mathrm{t}+2 \text {. This variable is inferred from the } \\
\text { average earnings-per-share (EPS) predictions by financial analysts as reported in } \\
\text { the month of June; }\end{array}$ \\
\hline BETA & $\begin{array}{l}\text { Beta of the stock in question. This variable is computed with a market model and } \\
\text { monthly data during the past } 4.5 \text { years. The market index for the SWX firms } \\
\text { (Panel A) is the Swiss Performance Index (SPI) and the Nasdaq Composite Index } \\
\text { for the Nasdaq firms (Panel B); }\end{array}$ \\
\hline LNVOLUME & $\begin{array}{l}\text { Natural logarithm of the average daily value of shares of the firm in question that } \\
\text { were traded during the past } 2.5 \text { years. Value is expressed in Swiss Francs for } \\
\text { SWX companies and U.S. Dollars for Nasdaq firms; }\end{array}$ \\
\hline RES-SIZE/LNVOL & $\begin{array}{l}\text { Residual of a regression of LNSIZE against LNVOLUME. LNSIZE is the natural } \\
\text { logarithm of the market capitalization of the firm's stock under analyses (SIZE). } \\
\text { The variable SIZE is computed as an average of six monthly observations. }\end{array}$ \\
\hline
\end{tabular}


Figure 2

Median illiquidity discounts for the holdout sample 1995-2001

This figure shows the median illiquidity discounts for holdout sample firms. The illiquidity discounts are calculated using the estimated coefficient for RELSP (Table 7) and the sample median spreads (Table 6) using equation (10).

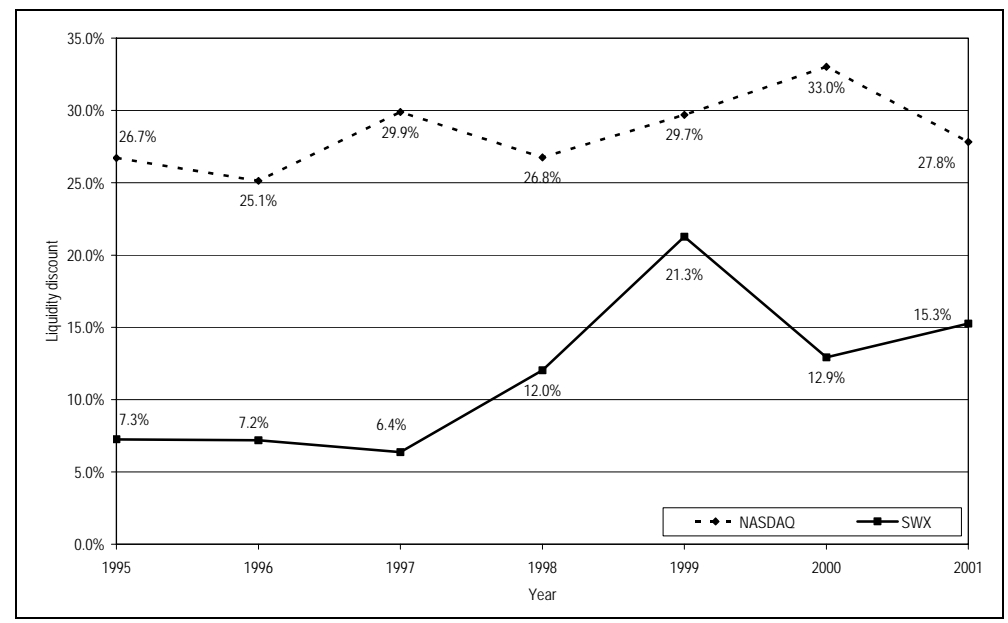


Table 9

Ten most liquid and least liquid firms: liquidity, risk, and firm value (original sample)

The table lists the ten most liquid and ten least liquid firms in the original sample. Reported are relative bid-ask spread, equity risk, and market capitalization of equity. In the table, $\mathrm{N}$ stands for Namenaktien (registered shares), I for Inhaberaktien (voting bearer shares), and GS for Genussscheine (nonvoting bearer shares).

\begin{tabular}{lccc|lccc}
\hline \multicolumn{3}{c|}{ Companies with the lowest bid-ask spread } & \multicolumn{3}{c}{ Companies with the highest bid-ask spread } \\
\hline & RELSP & Beta & $\begin{array}{c}\text { Size } \\
\left(\text { USD } 10^{6}\right)\end{array}$ & & RELSP & Beta & $\begin{array}{c}\text { Size } \\
\left(\text { USD } 10^{6}\right)\end{array}$ \\
ROCHE GS & $0.088 \%$ & 0.64 & 79,691 & WALTER MEIER I & $3.352 \%$ & 0.50 & 85.04 \\
NOVARTIS N & $0.089 \%$ & 0.80 & 133,132 & COS I & $3.495 \%$ & 0.31 & 222.82 \\
NESTLE N & $0.094 \%$ & 0.71 & 91,940 & BIG STAR I & $3.888 \%$ & 0.69 & 46.07 \\
SWISS RE N & $0.123 \%$ & 1.30 & 33,981 & LOEB PS & $3.963 \%$ & 0.26 & 43.25 \\
UBS N & $0.124 \%$ & 1.78 & 73,326 & SCHLATTER N & $4.001 \%$ & 0.69 & 61.60 \\
ZURICH ALLIED N & $0.187 \%$ & 1.60 & 27,986 & NETSTAL I & $4.031 \%$ & 0.43 & 337.88 \\
CS GROUP N & $0.191 \%$ & 1.83 & 63,472 & VETROPACK I & $4.070 \%$ & 0.41 & 39.70 \\
ABB LTD N 10 & $0.196 \%$ & 1.17 & 41,840 & GAVAZZI -B- I & $5.441 \%$ & 0.41 & 52.28 \\
ALUSUISSE N & $0.211 \%$ & 1.09 & 4,780 & PELIKAN I & $5.692 \%$ & 0.78 & 27.67 \\
HOLDERBK I & $0.223 \%$ & 0.98 & 7,777 & AGEFI N & $6.259 \%$ & 0.32 & 56.00 \\
& & & & & & & \\
\hline Median & $0.156 \%$ & 1.13 & 52,656 & Median & $4.016 \%$ & 0.42 & 54.14 \\
\hline
\end{tabular}

\begin{tabular}{|c|c|}
\hline Variable definitions & \\
\hline BETA & $\begin{array}{l}\text { Beta of the stock in question. This variable is computed with a market model } \\
\text { and monthly data during the period } 1.1 .1997 \text { to } 6.30 .2000 \text {; }\end{array}$ \\
\hline SIZE & $\begin{array}{l}\text { Market capitalization in million US Dollars of the most liquid class of stock of } \\
\text { the firm under analysis (calculated with an exchange rate of } 1.4 \mathrm{CHF} / \mathrm{USD} \text { ). } \\
\text { This variable is computed as an average of six monthly observations during } \\
\text { the period 1.1.2000 to } 6.30 .2000 \text {; }\end{array}$ \\
\hline RELSP & $\begin{array}{l}\text { Relative bid-ask spread, defined as the ratio of the difference between ask and } \\
\text { bid prices, divided by bid price. The spread is calculated as an average of two } \\
\text { daily observations (at } 10 \text { a.m. and } 4 \text { p.m.) during the period } 1.1 .1997 \text { to } \\
6.30 .2000 \text {. }\end{array}$ \\
\hline
\end{tabular}

